ORNL/TM-1999-243

\title{
An Assessment of the Economics of Future Electric Power Generation Options and the Implications for Fusion
}

\author{
Project Lead \\ J. G. Delene \\ Contributing Authors \\ J. Sheffield \\ K. A. Williams \\ R. L. Reid \\ S. Hadley
}


This report has been reproduced from the best available copy.

Reports are available to the public from the following source.

\author{
National Technical Information Service \\ 5285 Port Royal Road \\ Springfield, VA 22161 \\ Telephone 703-605-6000 (1-800-553-6847) \\ TDD 703-487-4639 \\ Fax 703-605-6900 \\ E-mail orders@ntis.fedworld.gov \\ Web site http://www.ntis.gov/ordering.htm
}

Reports are available to U.S. Department of Energy (DOE) employees, DOE contractors, Energy Technology Data Exchange (ETDE) representatives, and International Nuclear Information System (INIS) representatives from the following source.

Office of Scientific and Technical Information

P.O. Box 62

Oak Ridge, TN 37831

Telephone 423-576-8401

Fax 423-576-5728

E-mail reports@adonis.osti.gov

Web site http://www.osti.gov/products/sources.html

Reports produced after January 1, 1996, are generally available via the DOE Information Bridge.

Web site http://www.doe.gov/bridge

This report was prepared as an account of work sponsored by an agency of the United States Government. Neither the United States Government nor any agency thereof, nor any of their employees, makes any warranty, express or implied, or assumes any legal liability or responsibility for the accuracy, completeness, or usefulness of any information, apparatus, product, or process disclosed, or represents that its use would not infringe privately owned rights.

Reference herein to any specific commercial product, process, or service by trade name, trademark, manufacturer, or otherwise, does not necessarily constitute or imply its endorsement, recommendation, or favoring by the United States Government or any agency thereof. The views and opinions of authors expressed herein do not necessarily state or reflect those of the United States Government or any agency thereof. 
ORNL/TM-1999-243

Engineering Technology Division

\title{
AN ASSESSMENT OF THE ECONOMICS OF FUTURE ELECTRIC POWER GENERATION OPTIONS AND THE IMPLICATIONS FOR FUSION
}

\author{
Project Lead \\ J. G. Delene* \\ Contributing Authors \\ J. Sheffield ${ }^{\dagger}$ \\ K. A. Williams \\ R. L. Reid \\ S. Hadley
}

*Consultant.

$\dagger^{\dagger}$ Executive Director, ORNL/TVA/UTK Joint Institute for Energy \& Environment.

*Energy Division.

Date Published: September 1999

\author{
Prepared by the \\ OAK RIDGE NATIONAL LABORATORY \\ Oak Ridge, Tennessee 37831 \\ managed by \\ LOCKHEED MARTIN ENERGY RESEARCH CORP. \\ for the \\ U.S. DEPARTMENT OF ENERGY \\ under contract DE-AC05-96OR22464
}





\section{CONTENTS}

Page

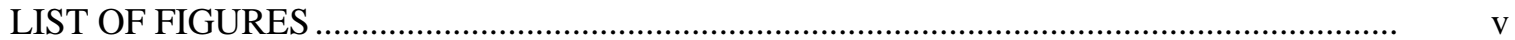

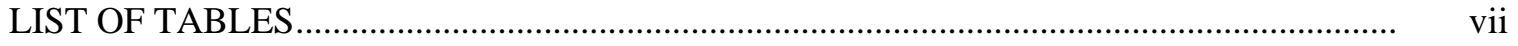

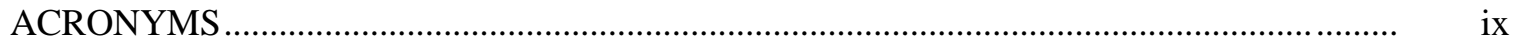

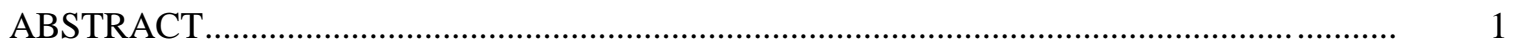

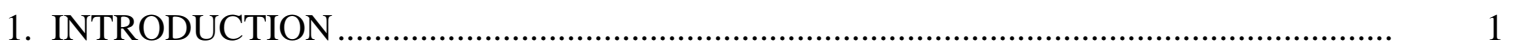

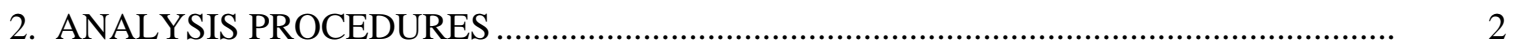

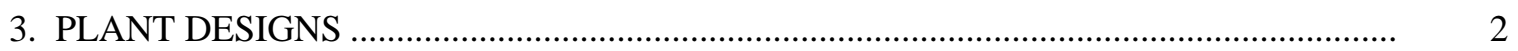

4. COST MODELS............................................................................................

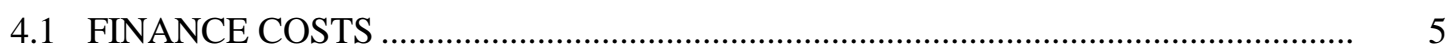

4.2 CAPITAL INVESTMENT COSTS ……….......................................................... 5

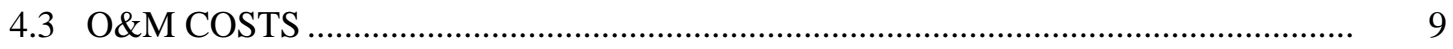

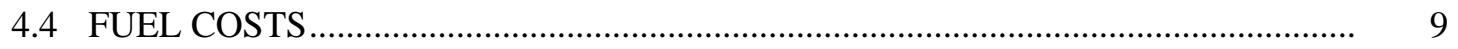

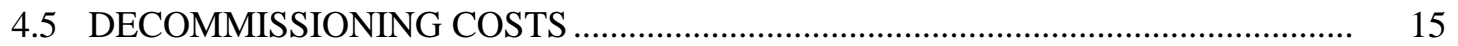

4.6 EMISSIONS ABATEMENT COSTS _................................................................ 15

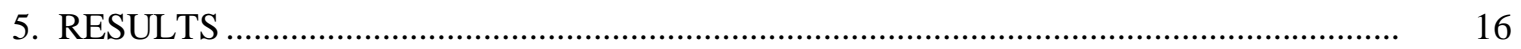

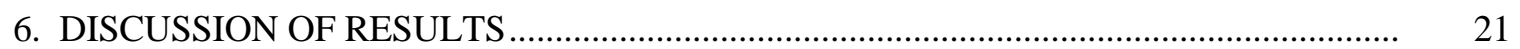

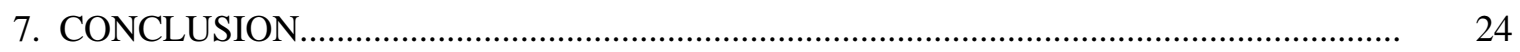

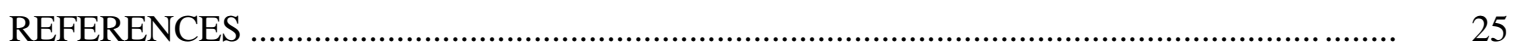




\section{LIST OF FIGURES}

$\begin{array}{lll}\text { Figure } & \text { Page }\end{array}$

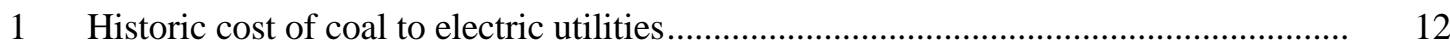

2 Price paid by electric utilities for natural gas............................................................... 12

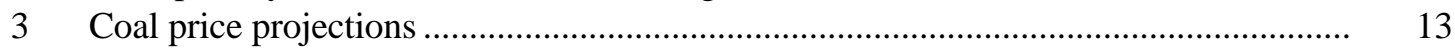

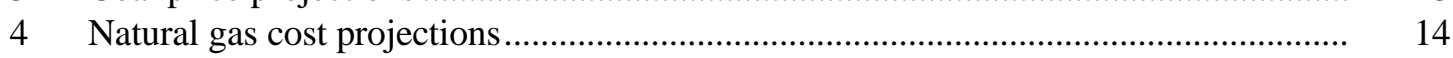

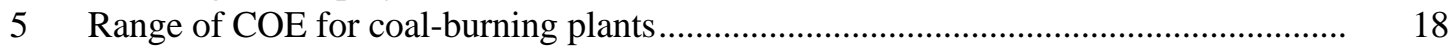

$6 \quad$ Range of COE for coal gasification plants................................................................. 18

$7 \quad$ Range of COE for natural gas...................................................................................... 19

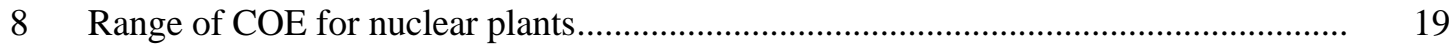

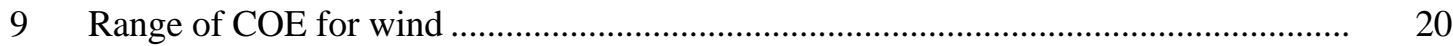

$10 \quad$ Range of COE for fusion power plants ........................................................................ 21

11 Range of COE for concepts without carbon sequestration........................................... 22

12 Range of COE for concepts including carbon sequestration.......................................... 22

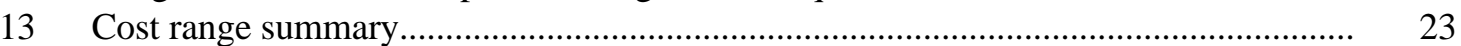




\section{LIST OF TABLES}

$\begin{array}{lll}\text { Table } & \text { Page }\end{array}$

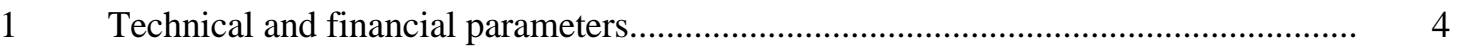

2 Coal-fired plant construction costs ......................................................................... 5

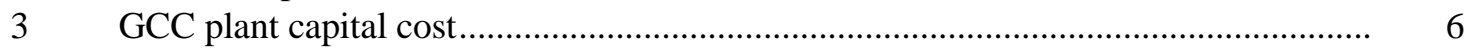

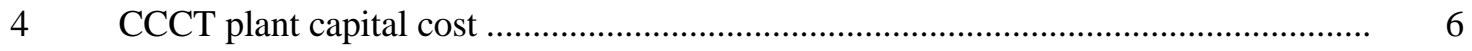

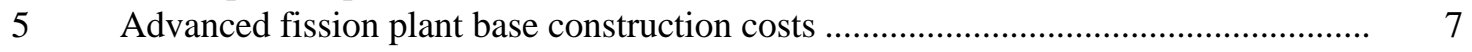

$6 \quad$ Wind turbine electric generation plant capital cost ................................................. 8

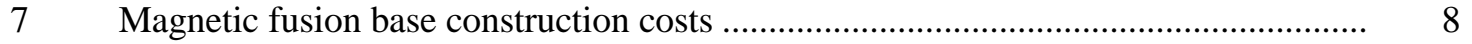

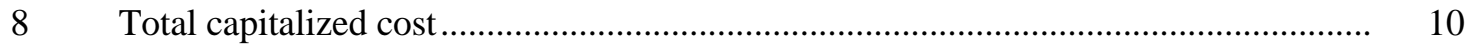

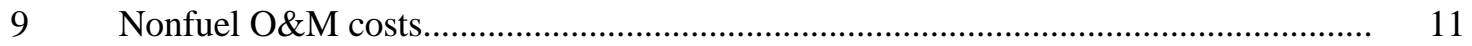

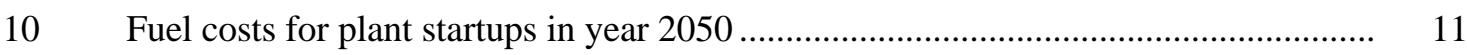

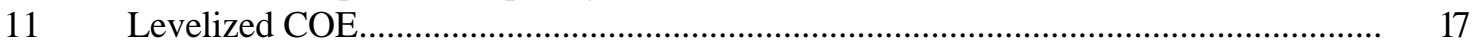




\section{ACRONYMS}

AFUDC allowance for funds used during construction

ALMR advanced liquid-metal reactor

ALWR advanced light-water reactor

ARIES Advanced Reactor Innovation and Evaluation Studies

BWR boiling-water reactor

CCCT natural gas-fired combined cycle combustion turbine

CEG cost estimating guideline

COE cost of electricity

DOE Department of Energy

EEDB Energy Economic Data Base

EIA Energy Information Administration

EPRI Electric Power Research Institute

GCC coal gasification combined cycle

GW(e) gigawatt ( $10^{9}$ watts) of electricity

HM heavy metal (uranium and plutonium in a fuel assembly)

IFE inertial fusion energy

ION refers to ion drivers with inertial fusion energy

$\mathrm{kg} \quad$ kilogram

$\mathrm{kWh} \quad$ kilowatt $\left(10^{3}\right.$ watts) hour of electricity

LASER laser drivers with inertial fusion plants

lb pound

LEU low-enriched uranium

LWR light-water reactor

MBtu million British thermal units

MHR gas-cooled modular helium reactor

MW(e) megawatt ( $10^{6}$ watts) of electricity

MOX mixed (uranium and plutonium) oxide

NECDB Nuclear Energy Cost Data Base

NOAK Nth-of-a-kind

ORNL Oak Ridge National Laboratory

O\&M Operation and Maintenance

PC-FGD pulverized coal-burning plant with flue gas desulfurization

PFBC pressurized fluidized-bed combustion

PWR pressurized-water reactor

RS reverse shear

SWU separative work unit

TAG ${ }^{\mathrm{TM}}$ technical assessment guide

TC technology characterization

tonne metric ton (1000 kilograms)

USCEA U.S. Council for Energy Awareness 


\title{
AN ASSESSMENT OF THE ECONOMICS OF FUTURE ELECTRIC POWER GENERATION OPTIONS AND THE IMPLICATIONS FOR FUSION
}

\author{
J. G. Delene J. Sheffield \\ K. A. Williams R. L. Reid \\ S. Hadley
}

\begin{abstract}
This study examines the potential range of electric power costs for some major alternatives to fusion electric power generation when it is ultimately deployed in the middle of the 21 st century and, thus, offers a perspective on the cost levels that fusion must achieve to be competitive. The alternative technologies include coal burning, coal gasification, natural gas, nuclear fission, and renewable energy. The cost of electricity (COE) from the alternatives to fusion should remain in the 30-50 mills/kWh (1999 dollars) range of today if carbon sequestration is not needed, 30-60 mills/kWh if sequestration is required, or as high as $75 \mathrm{mills} / \mathrm{kWh}$ for the worst-case scenario for cost uncertainty. The reference COE range for fusion was estimated at 70-100 mills/kWh for 1- to 1.3-GW(e) scale power plants. Fusion costs will have to be reduced and/or alternative concepts devised before fusion will be competitive with the alternatives for the future production of electricity. Fortunately, there are routes to achieve this goal.
\end{abstract}

\section{INTRODUCTION}

The ultimate viability of the fusion option will depend on its economic competitiveness with other options available in the same time frame. The purpose of this study is to examine the potential range of electric power costs for some major alternatives to fusion in the time frame where fusion will be available and, thus, offer a perspective on the cost levels that fusion must achieve to be competitive. It is projected that electric generation from fusion could be a contender for electric supply toward the middle of the 21 st century. We have, therefore, chosen a nominal plant startup date of 2050 for this study of competing power generation options.

The 1997 electric generating capacity in the United States was $747 \mathrm{GW}(\mathrm{e}) .{ }^{1}$ In its reference case projections, ${ }^{2}$ the Department of Energy (DOE) Energy Information Administration (EIA) predicts that this capacity will grow to $974 \mathrm{GW}$ (e) by 2020 with a range of 906-1044 GW(e) for the low- and high-growth projections. Continuing the 2010-2020 growth rate yields expected generating capacity needs of 1200-1700 GW(e) by 2050. The large number of plant additions, both for new capacity and to replace plant shutdowns, implies that no single technology will meet the entire need. The best policy for the long term should be to depend on a balanced mixture of energy sources. Current (1998) power generation ${ }^{1}$ is dominated by coal at $52 \%$; with nuclear, 19\%; natural gas, $15 \%$; conventional hydro, $9 \%$; petroleum, $3 \%$; and others, $2 \%$. Although other sources of electric power are always possible, especially 50 years in the future, coal will probably remain the dominant contender. The U.S. coal resources are immense. ${ }^{3}$ The estimated recoverable reserves of coal are adequate to last about 250 years at current (1997) U.S. coal production rates. The total U.S. identified coal resource is equal to more than 1500 years at 1997 mining rates. With advanced technology, some of the presently unrecoverable coal resources could be converted into recoverable reserves, thereby extending the duration of any coal-based energy option far into the future. 
Nuclear fission and gas-fired technologies should also remain as viable alternatives for future large-scale base-load power generation. It is expected that renewable energy sources such as wind power and solar photovoltaic electric power will also be viable in some localities. Some technologies, however, may have environmental and safety concerns that may add to their cost or even eventually make them unacceptable.

There are concerns about fossil fuel burning technologies and their greenhouse gas emissions. Improved plant efficiencies and coal gasification with $\mathrm{CO}_{2}$ sequestering can significantly reduce the amount of $\mathrm{CO}_{2}$ released to the atmosphere per kilowatt hour of electricity generated, but with incremental costs. Future fission reactors will reduce some of nuclear power's safety concerns with their "passive safety" features. Such concepts include advanced light-water reactors (ALWRs), advanced liquid-metal reactors (ALMRs), and gas-cooled modular helium reactors (MHRs). These concepts offer the prospect of reduced costs in addition to improved safety and environmental impact.

This report presents estimates of the projected cost of electricity (COE) from advanced coalfired plants [both a pulverized coal with flue gas desulfurization (PC-FGD) and the pressurized fluidized-bed combustion plant (PFBC)], a coal-gasification combined cycle (GCC), the ALWR and ALMR nuclear fission plants, a combined cycle natural gas-fired combustion turbine (CCCT), and a wind turbine power generator. This later technology is used as a surrogate for the renewables. The cost estimates from these technologies are compared with projected costs for fusion power.

\section{ANALYSIS PROCEDURES}

The basic data used to derive plant costs were obtained from published information and from industry sources. These data were adjusted for consistency with Oak Ridge National Laboratory (ORNL) methodologies and cost factors as given in the "Nuclear Energy Cost Data Base"4 (NECDB) and the "Cost Estimate Guidelines for Advanced Nuclear Power Technologies"5 (CEG). The NECDB methodology was developed for fission reactor studies, but it also provides a basis for consistent comparisons between fusion and alternatives. The CEG was developed to provide comparable cost estimates for advanced fission reactor concepts. It follows the NECDB in general methodology and provides uniform procedures, guidelines, and cost factors for developing cost estimates. Cost models include capital costs, operation and maintenance (O\&M) costs, fuel costs and $\mathrm{CO}_{2}$ sequestering, and plant decommissioning costs where applicable. The basic cost information available is often in differing years' dollars. All costs were adjusted to constant 1999 dollars to provide a consistent comparison.

Bottom-line capital investment costs and the unit COE are compared for all plant types considered. The resulting COE in mills per kilowatt hour is quoted in constant 1999 dollars.

\section{PLANT DESIGNS}

Fossil. The fossil-fired plants are of advanced design. It is expected that the PC-FGD plant of today will give way to the more efficient PFBC plant in the future. The PFBC plant is more efficient, but it will still have large $\mathrm{CO}_{2}$ emissions. To reduce or even eliminate $\mathrm{CO}_{2}$ emissions in the future, a $\mathrm{GCC}$ with a combined cycle gas turbine and $\mathrm{CO}_{2}$ sequestering is also included. The use of natural gas as a combustion fuel should also remain a competitor. A CCCT is included as the gas-burning technology. The PC-FGD, PFBC, GCC, and the CCCT plants are based on 
technical and cost information given in the Electric Power Research Institute (EPRI) technical assessment guide $\left(\right.$ TAG $\left.^{\mathrm{TM}}\right)$ document. $^{6}$

Fission. Several ALWR designs may provide the basis for a resurgence of the nuclear fission option. These include large evolutionary plant designs by General Electric ${ }^{7}$ and ABBCombustion Engineering, ${ }^{8}$ as well as a smaller passively safe plant designed by Westinghouse. ${ }^{9}$ For this study we have chosen a large ALWR plant consistent with a U.S. Council for Energy Awareness (USCEA) cost study. ${ }^{10}$ The COE from this plant design is taken as representative of all the ALWR designs, including pressurized-water reactors (PWRs) and boiling-water reactors (BWRs).

The General Electric ALMR design ${ }^{11}$ is a modular fast reactor concept consisting of three modules with a modular power of $496 \mathrm{MW}$ (e) each. Several fuel schemes were proposed for this reactor. We considered one for a break-even breeder (produces as much fuel as it consumes) for this study.

In addition to the ALWR and ALMR fission reactor concepts, the MHR could become a contender in the next century. As with the ALMR, there are advantages due to smaller size units because reactor components and structures might be factory-produced instead of site-constructed. Also, the high temperature and the use of a direct cycle lead to higher thermal efficiencies. The South African utility ESKOM is developing a pebble-bed version ${ }^{12}$ of this option in conjunction with European and Russian partners. In the United States, General Atomics is developing a prismatic fuel concept ${ }^{13}$ with Russia as part of a weapons plutonium disposition project. The economics for these options are not available at this time.

Wind. A wind generator plant is considered here as a surrogate for renewable energy sources. The worldwide installed capacity of wind turbines has been growing at the rate of $22 \%$ per year ${ }^{14}$ since 1991 and appears to be accelerating with a $35 \%$ growth rate ${ }^{14}$ in 1998 . Worldwide capacity now exceeds $10 \mathrm{GW}(\mathrm{e})^{14}$ and is projected to reach $20 \mathrm{GW}(\mathrm{e})^{15}$ in 2002 . The plant considered here consists of 100 tower-mounted wind turbines with a power of $1 \mathrm{MW}(\mathrm{e})$ each for a total station power of $100 \mathrm{MW}(\mathrm{e})$. This plant is based on information from the EPRI/DOE renewable energy technology characterization (TC) document. ${ }^{16}$ Wind turbine sizes are increasing with U.S. firms beginning to build 1- to 2-MW(e) machines and European firms exploring 5-MW(e) units. ${ }^{14}$ However, for now, unit "sizes near $1 \mathrm{MW}(\mathrm{e})$ appear to yield the approximate optimal trade-offs between cost, performance and reliability for large wind farm operations."16

Fusion. Magnetic fusion energy (MFE) reactor designs were also considered. Two tokamak fusion plants from the Advanced Reactor Innovation and Evaluation Studies (ARIES) design studies, the ARIES-RS and ARIES-ST, are examined. ${ }^{17,18}$ Inertial fusion energy (IFE) power plants such as those from the HYLIFE design ${ }^{19,20}$ series may also be contenders for economic fusion power in the future but are not included explicitly in this report.

Various technical parameters for the plants are shown in Table 1. For all plants except wind, a nominal capacity factor of $80 \%$ was used in the base case analysis with a range of $70-90 \%$. Nuclear plant designers claim that future nuclear plants will achieve capacity factors in the upper $80 \%$ range, with many of today's plants routinely achieving capacity factors in that range. For wind, a 35\% base capacity factor was chosen. This is consistent with the high end of the 1997 capacity factor range (26-36\%) for wind turbines. ${ }^{16}$ The possibility of siting wind turbines in areas with more favorable wind conditions and improvements in design could raise the capacity factor to the $45 \%$ level. A capacity factor range of $25 \%$ to $45 \%$ was used for wind turbines. The use of energy storage or gas turbines during periods of low wind could raise the overall system capacity factor into the $70 \%$ to $90 \%$ range considered for the other technologies. In this study, the CCCT technology is assumed to provide such a backup when applicable. 
Table 1. Technical and financial parameters

\begin{tabular}{|c|c|c|}
\hline Parameter & Reference value & Range \\
\hline \multicolumn{3}{|l|}{ Capacity factor, $\%$} \\
\hline Wind & 35 & $25-45$ \\
\hline Other than wind & 80 & $70-90$ \\
\hline \multicolumn{3}{|l|}{ Design and construction time, years } \\
\hline Coal-fired plants & 4 & \\
\hline GCC plants & 4 & \\
\hline CCCT plants & 2.75 & \\
\hline ALWR plants & 6 & \\
\hline ALMR plants & 5 & \\
\hline Fusion plants & 6 & \\
\hline Wind & 2 & \\
\hline \multicolumn{3}{|l|}{ Fossil plant heat rates, Btu/kWh } \\
\hline Pulverized coal & 9400 & $8500-9400$ \\
\hline PFBC coal & 8100 & $6800-8300$ \\
\hline GCC & 8100 & $6000-8500$ \\
\hline CCCT & 6900 & $5000-7000$ \\
\hline Levelization period, years & 30 & \\
\hline Reference cost year & 1999 & \\
\hline Year of plant startup & 2050 & \\
\hline Average inflation rate, $\%$ & 3 & \\
\hline Cost of money factors, $\%$ & Capitalization & Cost of Money \\
\hline Debt & 47 & $7.4(4.27)^{a}$ \\
\hline Preferred stock & 6 & $6.9(3.79)^{a}$ \\
\hline Common equity & 47 & $12.0(8.74)^{a}$ \\
\hline Cost of money during construction, $\%$ & $9.53(6.34)^{a}$ & \\
\hline Effective cost of money (discount rate), $\%$ & $8.18(5.02)^{a}$ & \\
\hline \multicolumn{3}{|l|}{ Income tax rates, $\%$} \\
\hline Federal & 35 & \\
\hline State & 6 & \\
\hline Combined & 38.9 & \\
\hline
\end{tabular}

${ }^{a}$ Real (inflation adjusted) parameters in parentheses.

The design and construction times shown for nuclear plants are shorter than past experience, but are consistent with foreign experience, such as in Japan and Korea, and with improved regulatory practices. Fossil plant heat rates have improved and could continue to improve. The reference heat rates shown are from the EPRI-TAG ${ }^{\mathrm{TM}}$. The low-end range values are consistent with DOE program goals. ${ }^{21}$ 


\section{COST MODELS}

\subsection{FINANCE COSTS}

The financial parameters, which form the economic basis for the COE estimates, are also shown in Table 1. Consistent with other past studies, a 30-year plant cost recovery period is used. The reference year for all costs in this report is January 1, 1999. A 2050 plant startup date was chosen as a date when large fusion electric plants could be available. The cost of money factors assume an average general inflation rate of $3 \%$ over the study period. The DOE-EIA projections ${ }^{2}$ show inflation increasing to 2020 . The rate exceeds $3 \%$ in the later years. We assume an eventual leveling off at the $3 \%$ rate. The cost of money is shown in nominal dollars with the constant dollar (with the inflation component removed) figure in parenthesis. The combined income tax rate assumes that state income taxes are deductible for federal income tax purposes, but not vice versa.

\subsection{CAPITAL INVESTMENT COSTS}

Fossil. The capital investment costs for the fossil-fired plants are based on cost models given in the EPRI-TAG ${ }^{\mathrm{TM}}$ escalated to 1999 dollars and scaled to the plant sizes considered. The PC-FGD costs are for a two-unit, $600 \mathrm{MW}(\mathrm{e})$ per unit plant. The PFBC plant costs are for a threeunit, $400 \mathrm{MW}(\mathrm{e})$ per unit plant, and the GCC investment costs are for a two-unit, $600 \mathrm{MW}(\mathrm{e})$ per unit plant. The CCCT plant is also based on information in the EPRI TAG ${ }^{\mathrm{TM}}$. The CCCT cost model in this paper assumes a four-unit plant with a unit capacity of $300 \mathrm{MW}(\mathrm{e})$. Base construction costs for the PC-FGD and PFBC plants are shown in Table 2. The base construction cost for the GCC plant is shown in Table 3, and the cost for the CCCT plant is given in Table 4. An uncertainty range is given for each of the technologies. The lower end of the range for coal-based technologies reflects DOE cost goals, while the upper end includes a bias of 5\% for PC-FGD, $10 \%$ for the PFBC, and $15 \%$ for the GCC. The upper end of the uncertainty range generally reflects the maturity of each concept. The CCCT cost range considers a 200-MW(e) plant to derive the high-end costs and a 400-MW(e) plant to derive the low-range costs.

Table 2. Coal-fired plant construction costs

\begin{tabular}{|c|c|c|}
\hline \multirow{4}{*}{ Account } & \multicolumn{2}{|c|}{ Capital investment cost (1999 \$M) } \\
\hline & PC-FGD & PFBC \\
\hline & \multicolumn{2}{|c|}{ Units $\times[\mathrm{MW}(\mathrm{e})$ per unit $]$} \\
\hline & $2 \times 600$ & $3 \times 400$ \\
\hline Land and land rights & 2 & 2 \\
\hline Steam generator & 563 & 552 \\
\hline Turbine generator & 339 & 204 \\
\hline Coal handling equipment & 119 & 108 \\
\hline Balance of plant & 120 & 218 \\
\hline Environmental capital & 207 & 0 \\
\hline General facilities and engineering & 187 & 202 \\
\hline Base construction cost & $\begin{array}{l}1538 \\
\quad[1282 \$ / \mathrm{kW}(\mathrm{e})]\end{array}$ & $\begin{array}{l}1287 \\
\quad[1072 \$ / \mathrm{kW}(\mathrm{e})]\end{array}$ \\
\hline Range, $\$ /$ kW(e) & $800-1350$ & $800-1180$ \\
\hline
\end{tabular}


Table 3. GCC plant capital $\operatorname{cost}^{a}$

\begin{tabular}{lc}
\hline \multicolumn{1}{c}{ Account } & Capital investment cost \\
& $(1999$ \$M) \\
\hline Land and land rights & 2 \\
Air separation & 172 \\
Gasification/gas cooling & 412 \\
Gas cleanup & 50 \\
Combined cycle & 523 \\
Other balance of plant & 102 \\
General facilities and engineering & 240 \\
Base construction cost & $1502[1252 \$ / \mathrm{kW}(\mathrm{e})]$ \\
Range, \$/kW(e) & $800-1440$ \\
\hline
\end{tabular}

$a_{\text {Two units }} \times 600 \mathrm{MW}(\mathrm{e})$ per unit.

Table 4. CCCT plant capital $\operatorname{cost}^{a}$

\begin{tabular}{lc}
\hline \multicolumn{1}{c}{ Account } & $\begin{array}{c}\text { Capital investment cost } \\
(1999 \$ \mathrm{M})\end{array}$ \\
\hline Land and land rights & 1 \\
Combustion turbine and auxiliaries & 193 \\
Heat recovery steam generator & 78 \\
Steam turbine, generator, and auxiliaries & 73 \\
General facilities and engineering & $\underline{245}$ \\
Base construction cost & $590[492 \$ / \mathrm{kW}(\mathrm{e})]$ \\
Range, $\$ / \mathrm{kW}(\mathrm{e})$ & $480-550$ \\
\hline
\end{tabular}

$a_{\text {Four units }} \times 300 \mathrm{MW}(\mathrm{e})$ per unit.

Fission. Capital investment costs for the ALWR and ALMR were derived from nuclear

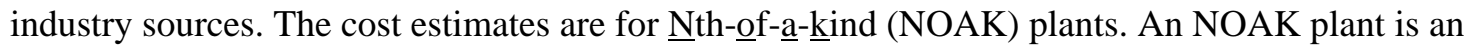
equilibrium commercial plant of identical design to previous plants of its type. NOAK plant costs include only those costs that are repetitive from plant to plant and reflect the experience of prior plants or a "learning curve" leading to the NOAK plant.

Cost models for the ALWR nuclear plants were derived from the same basic cost information used in the 1992 USCEA study. ${ }^{10}$ This information is for an evolutionary reactor with a unit size of about $1300 \mathrm{MW}(\mathrm{e})$. The USCEA costs were adjusted to 1999 dollars and a 1300-MW(e) unit size to obtain the capital costs in this study.

The ALMR capital costs are consistent with reported information. ${ }^{11,22}$ This information for a 1488-MW(e) total plant size was adjusted to 1999 dollars. Table 5 shows a breakdown of the base construction costs for both the ALWR and ALMR plants.

A nominal uncertainty range is also shown in Table 5. There is considerable uncertainty in the capital investment costs for future nuclear power plants. The uncertainty ranges considered do not reflect potential institutional problems, which could negate the nuclear option altogether. For the ALWR, the nominal uncertainty adds about $15 \%$ to the cost on the high end and subtracts 
Table 5. Advanced fission plant base construction costs

\begin{tabular}{|c|c|c|}
\hline \multirow{4}{*}{ Account } & \multicolumn{2}{|c|}{$\begin{array}{l}\text { Capital investment cost } \\
\qquad(1999 \text { \$M) }\end{array}$} \\
\hline & ALWR & ALMR \\
\hline & \multicolumn{2}{|c|}{ Units $\times[\mathrm{MW}(\mathrm{e})$ per unit $]$} \\
\hline & $1 \times 1300$ & $3 \times 496$ \\
\hline Land and land rights & 5 & 5 \\
\hline Structures and improvements & 339 & 360 \\
\hline Reactor plant equipment & 349 & 865 \\
\hline Turbine plant equipment & 331 & 263 \\
\hline Electric plant equipment & 97 & 115 \\
\hline Miscellaneous plant equipment & 63 & 39 \\
\hline Heat rejection system & 70 & 38 \\
\hline Total direct costs & 1255 & 1685 \\
\hline Construction services & 291 & 170 \\
\hline Home office engineering and services & 74 & 125 \\
\hline Field office engineering and services & 108 & 83 \\
\hline Base construction cost & $\begin{array}{l}1728 \\
{[1329 \$ / \mathrm{kW}(\mathrm{e})]}\end{array}$ & $\begin{array}{l}2063 \\
{[1386 \$ / \mathrm{kW}(\mathrm{e})]}\end{array}$ \\
\hline Range, $\$ / \mathrm{kW}(\mathrm{e})$ & $1200-1530$ & $1200-1730$ \\
\hline
\end{tabular}

about $10 \%$ on the low end. For the ALMR, the cost is the same dollar per kilowatt hour cost as the ALWR on the low end and 25\% above the reference ALMR cost for the high end of the uncertainty range.

Wind. Wind was chosen for this study as a stand-in for the other renewable energy sources such as solar photovoltaic. Renewables, such as wind and solar photovoltaic, will not be practical in all regions of the country because they depend on the availability of the forces of nature, such as the wind blowing and on the latitude and cloud cover. They can, however, offer an attractive economic choice in various regions of the country and for specific applications. The wind turbine cost model was derived from the EPRI/DOE Renewable Energy Characterization TC Study. ${ }^{16}$ The capital investment costs from the TC report were adjusted to 1999 dollars. These costs are for a 1-MW(e) unit size and a 50-MW(e) station. The TC costs were reduced by $5 \%$ for the 100-MW(e) station considered here. ${ }^{16}$ There are economies of scale with station size. Larger size stations, which may be present toward the middle of the next century, should cut costs even further. A breakdown of the base construction cost for a wind turbine plant is shown in Table 6. A nominal $\pm 20 \%$ uncertainty range is shown for wind turbines consistent with the uncertainty range in the TC document. This is a developing technology with expected increases in turbine size and efficiency and room for other technological improvements in the next 50 years. The principal uncertainty in wind turbine electric generation performance and economics is the plant capacity factor.

Fusion. Construction cost information for the MFE designs was escalated to 1999 dollars. The base construction cost breakdowns for the magnetic confinement ARIES-RS and ARIES-ST designs are shown in Table 7. The ARIES power plant studies ${ }^{17,18}$ are referenced here because they use a costing methodology consistent with other costs in this paper. There are also studies 19,20 for IFE for which the costing approach differs. These IFE studies show lower costs than those given in the ARIES studies for the structures and improvements, turbine plant equipment and electric plant equipment accounts for the same electric output plants. In the future, 
Table 6. Wind turbine electric generation plant capital $\operatorname{cost}^{a}$

\begin{tabular}{lc}
\hline \multicolumn{1}{c}{ Account } & $\begin{array}{c}\text { Capital investment cost } \\
(1999 \$ \mathrm{M})\end{array}$ \\
\hline Land and land rights & 1 \\
Rotor assembly & 14.1 \\
Tower & 23.7 \\
Generator & 4.1 \\
Electrical & 6.6 \\
Transmission and drive train & 3.0 \\
Balance of system & \\
Base construction cost & 12.6 \\
Range, $\$ / \mathrm{kW}(\mathrm{e})$ & $65.2[650 \$ / \mathrm{kW}(\mathrm{e})]$ \\
\hline
\end{tabular}

$a_{100}$ units $\times 1 \mathrm{MW}(\mathrm{e})$ per unit.

$b$ Includes facilities, engineering, and owner's cost.

Table 7. Magnetic fusion base construction costs

\begin{tabular}{|c|c|c|}
\hline \multirow[b]{2}{*}{ Account } & \multicolumn{2}{|c|}{$\begin{array}{l}\text { Construction cost }{ }^{a} \\
\qquad(1999 \text { \$M) }\end{array}$} \\
\hline & ARIES-RS & ARIES-ST \\
\hline Land and land rights & 5 & 5 \\
\hline Structures and improvements & 399.7 & 432.3 \\
\hline Reactor plant equipment & 1600.0 & 1534.9 \\
\hline Turbine plant equipment & 344.2 & 410.5 \\
\hline Electric plant equipment & 130.4 & 147.9 \\
\hline Miscellaneous plant equipment & 66.2 & 91.8 \\
\hline Heat rejection system & $b$ & 69.5 \\
\hline Special materials & 13.1 & 128.4 \\
\hline Total direct costs & 2558.6 & 2820.3 \\
\hline Construction and engineering services & 562.9 & 620.5 \\
\hline Total base construction cost & $3121.5[3120 \$ / \mathrm{kW}(\mathrm{e})]$ & $3440.8[3440 \$ / \mathrm{kW}(\mathrm{e})]$ \\
\hline Range, ${ }^{c} \$ / \mathrm{kW}(\mathrm{e})$ & $2700-3120$ & $3045-3440$ \\
\hline
\end{tabular}

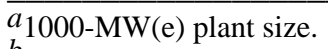

$b$ Included with reactor plant equipment.

${ }^{c}$ Range for 1000 - to $1300-\mathrm{MW}$ (e) plant sizes. 
resolutions of costing methodology differences are needed. The reference costs for the fusion designs are for a 1000-MW(e) plant size. Because fusion island costs are a weak function of plant size, an increase in the fusion plant size will lead to a lower COE, opening one route to competitive fusion energy. The low end of the cost range shown in Table 7 assumes a 1300-MW(e) plant size consistent with the size of the ALWR plant.

The breakdown of the base capital cost for nuclear fission follows the Energy Economic Data Base (EEDB) code of accounts. The base cost breakdowns for the other plants follow the account structure provided in the source documentation. The indirect costs (construction services, engineering costs, and owner's cost) for the fusion plants were assumed to be the same percentage of direct costs as for the ALWR.

Tables 2-7 showed the base construction costs before owner's cost and contingency. Table 8 contains the total capitalized cost for the various plants. Owner's costs are based on proponent estimates and on information from the EPRI-TAG ${ }^{\mathrm{TM}}$. The same percentage was used for fusion plants as for the ALWR. Contingency factors will depend on the state of development of the technology. Contingency factors were applied to the sum of all other costs for each concept as follows: fusion plants 20\%; ALMR fission, 17.5\%; ALWR, PFBC, and GCC plants, 15\%;

PC-FGD, CCCT, and wind turbine plants, $10 \%$. These contingencies reflect design uncertainties only and do not include the possible effects of major technology difficulties (or advancements) or large construction schedule delays. Calculation of interest during construction assumes a chopped cosine spending pattern during construction. The design and construction times were shown in Table 1. Other construction cash flow profiles will give somewhat different capitalization factors.

\subsection{O\&M COSTS}

The O\&M costs for each of the plants considered are shown in Table 9. These are divided into a fixed cost $[\$ / \mathrm{kW}(\mathrm{e})$ per year] and a variable cost (mill/ $/ \mathrm{kWh})$. The costs for the nuclear fission and fossil-fired plants are based on calculations performed using an updated version of the ORNL O\&M cost code, OMCOST. ${ }^{23}$ The O\&M costs for the wind turbine are those given in the renewable energy TC document ${ }^{16}$ adjusted to 1999 dollars. The O\&M costs for fusion plants should be similar to those for the advanced fission plants at the same level of safety assurance. The fusion O\&M costs were assumed to be the same as for a passively safe ALWR, adjusted for unit size. All costs were adjusted to 1999 dollars.

\subsection{FUEL COSTS}

Fuel cost assumptions used for the study are shown in Table 10. Future fossil fuel and nuclear fuel prices are very uncertain. In past studies, ${ }^{24,25}$ projections of rapidly increasing fuel commodity prices have been used to justify the competitiveness of various advanced concepts. Recent history indicates that assumptions of increasing real fuel prices may be foolhardy.

Fossil. The real prices paid by electric utilities for $\operatorname{coal}^{26,27}$ and natural gas ${ }^{28}$ since 1980 , adjusted to 1999 dollars, are shown in Figs. 1 and 2. These figures show a steady decrease in the price of coal and, since 1990, a generally flat price for natural gas. The price of coal reflects strong year-to-year increases in mine productivity and a competitive world market. The recent annual variability in the price of natural gas reflects seasonal demand differences and an adequate supply.

The DOE-EIA makes projections of the future price of fossil fuels as part of its annual energy outlook report. ${ }^{2}$ These projections currently run through 2020 . The average projected 
Table 8. Total capitalized cost

\begin{tabular}{|c|c|c|c|c|c|c|c|c|c|}
\hline & \multicolumn{3}{|c|}{ Coal technologies } & \multicolumn{2}{|c|}{ Nuclear fission } & \multirow{2}{*}{$\frac{\mathrm{Gas}}{\mathrm{CCCT}}$} & \multirow{2}{*}{$\frac{\text { Renewable }}{\text { Wind }}$} & \multicolumn{2}{|c|}{ Magnetic fusion } \\
\hline & PC-FGD & PFBC & GCC & ALWR & ALMR & & & ARIES-RS & ARIES-ST \\
\hline Base construction cost & 1538 & 1287 & 1502 & 1728 & 2063 & 590 & 65.2 & 3121 & 3441 \\
\hline Owners' cost & 132 & 69 & 87 & 240 & 264 & 17 & $a$ & 400 & 440 \\
\hline Contingency & 167 & 207 & 238 & 295 & 406 & 61 & 6.5 & 704 & 776 \\
\hline Overnight cost & 1837 & $\overline{1559}$ & $\overline{1827}$ & 2263 & 2734 & 668 & $\overline{71.7}$ & $\overline{4225}$ & 4657 \\
\hline AFUDC cost & 305 & 248 & 304 & 387 & 398 & 70 & 3.8 & 722 & 796 \\
\hline Total construction cost & & & & & & & & & \\
\hline $\begin{array}{l}\text { Millions of } 1999 \text { dollars } \\
\text { Dollars per }\end{array}$ & 2142 & 1807 & 2131 & 2650 & 3132 & 738 & 75.5 & 4947 & 5453 \\
\hline kilowatt electric & 1785 & 1506 & 1776 & 2038 & 2105 & 615 & 755 & 4947 & 5453 \\
\hline Range, $\$ / k W(e)$ & & & & & & & & & \\
\hline Low & 1140 & 1125 & 1135 & 1835 & 1835 & 580 & 620 & $4275^{b}$ & $4380^{b}$ \\
\hline High & 1875 & 1665 & 2040 & 2345 & 2630 & 670 & 920 & $4950^{c}$ & $5450^{c}$ \\
\hline
\end{tabular}

${ }^{a}$ Included in base construction cost.

${ }^{b}$ Low based on 1300-MW(e) plant size.

${ }^{c}$ High based on 1000-MW(e) plant size. 
Table 9. Nonfuel O\&M costs

\begin{tabular}{lccc}
\hline \multicolumn{1}{c}{ Plant type } & $\begin{array}{c}\text { Fixed cost } \\
{[\$ / \mathrm{kW}(\mathrm{e}) \text { per year }]}\end{array}$ & $\begin{array}{c}\text { Variable cost } \\
(\mathrm{mill} / \mathrm{kWh})\end{array}$ & $\begin{array}{c}\text { O\&M cost } \\
(\mathrm{mill} / \mathrm{kWh})\end{array}$ \\
\hline ALWR & 57.6 & 0.4 & 8.6 \\
ALMR & 70.2 & 0.4 & 10.4 \\
PC-FGD coal & 36.7 & 3.2 & 8.5 \\
PFBC & 36.8 & 2.0 & 7.2 \\
GCC-coal gasification & 54.8 & 1.6 & 9.4 \\
CCCT_natural gas & 28.1 & 0.5 & 4.5 \\
Wind turbine & 14.2 & 0.0 & 4.6 \\
Fusion & 60.0 & 0.4 & 9.0 \\
\hline
\end{tabular}

$a_{\text {At reference plant size and capacity factors. }}$

Table 10. Fuel costs for plant startups in year 2050

\begin{tabular}{|c|c|c|}
\hline & \multicolumn{2}{|c|}{1999 dollars } \\
\hline & Reference & Range \\
\hline \multicolumn{3}{|l|}{ Nuclear fuel prices } \\
\hline Uranium, $\$ / \mathrm{lb} \mathrm{U}_{3} \mathrm{O}_{8}$ & 25 & $15-145$ \\
\hline Conversion, \$/kg uranium & 7 & $4-7$ \\
\hline Enrichment, \$/SWU & 80 & $40-100$ \\
\hline $\begin{array}{l}\text { Low-enriched uranium (LEU) } \\
\text { fabrication, } \$ / \mathrm{kg} \text { uranium }\end{array}$ & 270 & $200-300$ \\
\hline $\begin{array}{l}\text { LWR mixed-oxide (MOX) fuel } \\
\$ / \mathrm{kg} \text { heavy metal (HM) }\end{array}$ & 3200 & $2000-4000$ \\
\hline ALMR fuel recycle, $\$ / \mathrm{kg} \mathrm{HM}$ & 5150 & $4600-7700$ \\
\hline Waste disposal, mill/kWh & 1 & $0.5-1.5$ \\
\hline \multicolumn{3}{|l|}{ Fossil fuel prices, $\$ / \mathrm{MBtu}$} \\
\hline Coal & 1.00 & $0.60-1.35$ \\
\hline Natural gas & 3.85 & $2.90-5.05$ \\
\hline \multicolumn{3}{|l|}{$\mathrm{CO}_{2}$ capture and sequestration costs } \\
\hline \multicolumn{3}{|l|}{ Energy penalty, $\%$} \\
\hline PC-FGD and PFBC & 15 & $12-18$ \\
\hline CCG and CCCT & 10 & $8-12$ \\
\hline Other costs, $\$ /$ tonne $\mathrm{CO}_{2}$ & 10 & $5-15$ \\
\hline
\end{tabular}




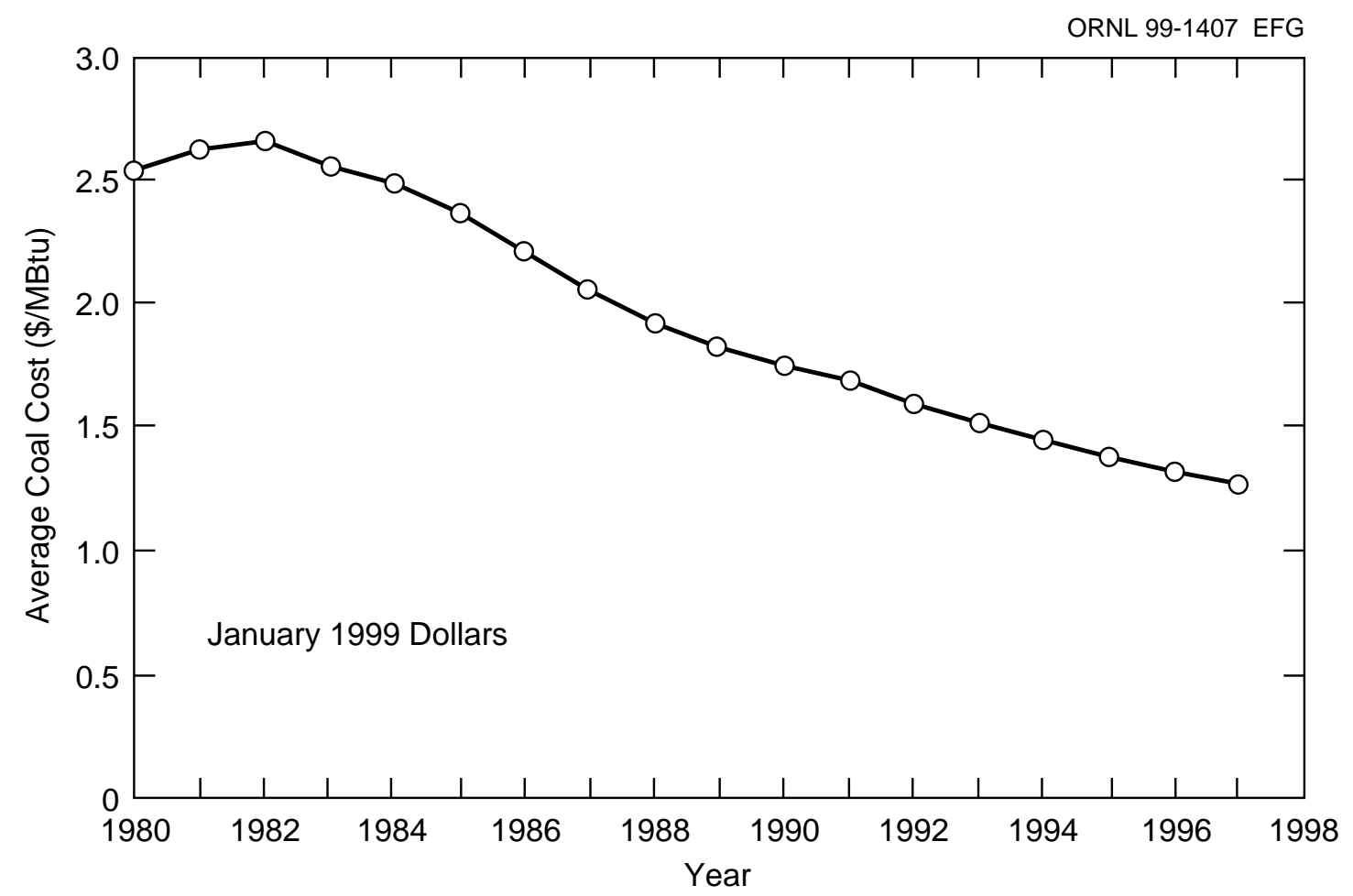

Fig. 1. Historic cost of coal to electric utilities.

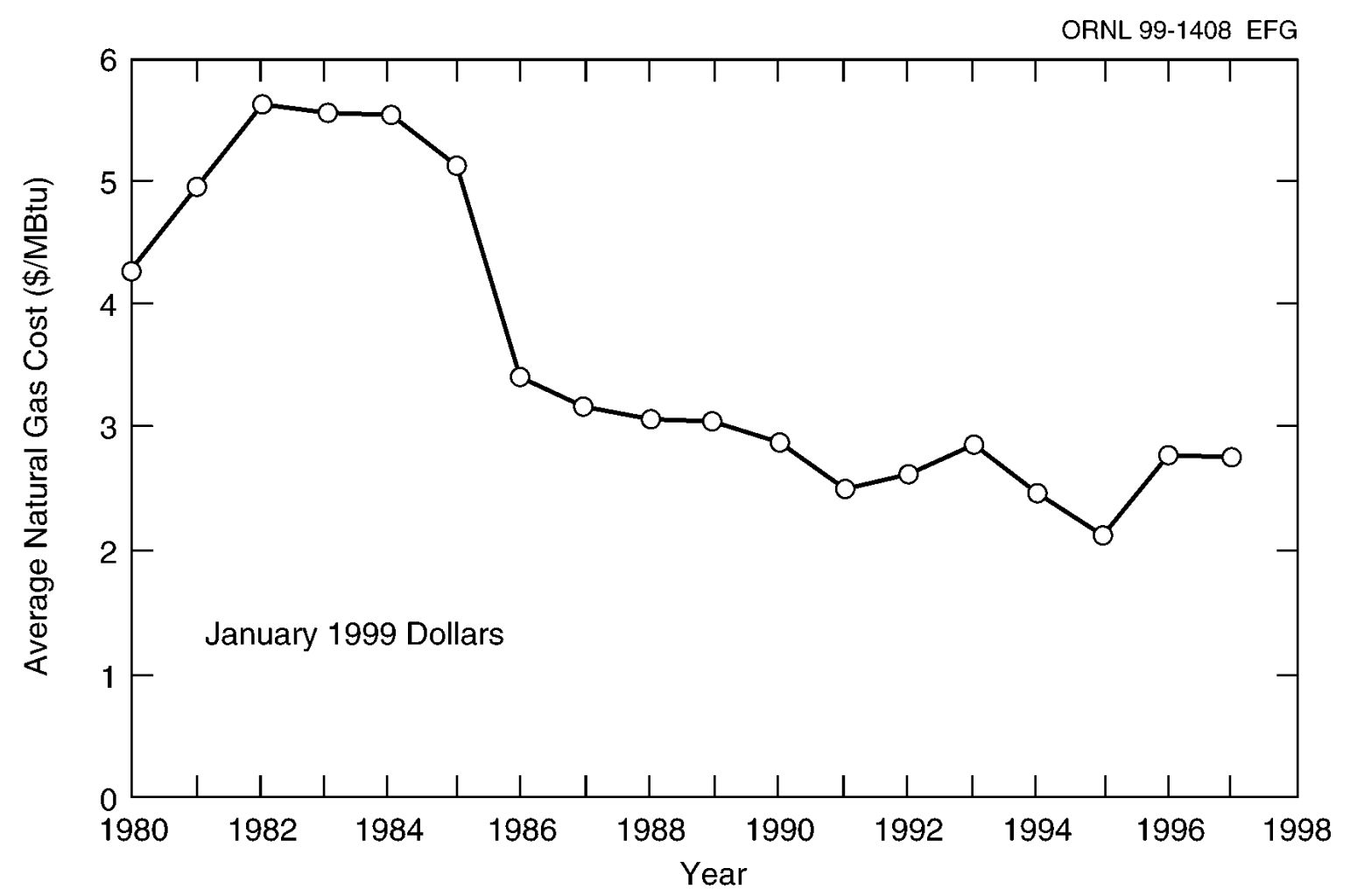

Fig. 2. Price paid by electric utilities for natural gas. 
prices that utilities pay for coal and natural gas through 2020 for the low-growth, midgrowth, and high-growth EIA projections are shown in Fig. 3 for coal and in Fig. 4 for natural gas. The reference value in this report of $\$ 1 / \mathrm{MBtu}$ for coal assumes a small recovery and then a leveling off of the cost of coal as demand strengthens with the need for more electric energy. The low projection assumes that the EIA low-growth price projection for coal continues to decline before leveling off at $\$ 0.60 / \mathrm{MBtu}$ in the year 2050. The high coal projection assumes that the price of coal escalates in real terms at $1 \%$ per year from the EIA 2020 high projection before leveling off at \$1.35/MBtu (1999 dollars) after 2050.

The reference gas price is based on the DOE-EIA midgrowth case with a continued real price escalation at the 2010-2020 growth rate (about $0.51 \%$ per year) to 2050 with a leveling off at $\$ 3.85 / \mathrm{MBtu}$ (1999 dollars) after 2050. The low-range case assumes a continuation of the DOE-EIA low-growth case projection, which shows no real growth in the price of natural gas past 2010. The high-range gas price assumes a continuation of the EIA high-growth projection (about 1\% per year) leveling off at \$5.05/MBtu (1999 dollars) after the year 2050.

Fission. Nuclear fuel prices have also decreased. Uranium spot market prices ${ }^{29}$ have recently been in the range of $\$ 9-\$ 12 / \mathrm{lb}$ of $\mathrm{U}_{3} \mathrm{O}_{8}$. The current uranium price reflects the market dampening effect of Russian uranium and uranium from the dismantling of weapons being directed toward the civilian market. If the nuclear industry revives, the price of uranium will have to rise to a point where it is economical to open new mines. Other costs such as fuel enrichment have also decreased with a current price quoted ${ }^{30}$ of $\$ 87 / \mathrm{SWU}$. The costs for the other nuclear fuel components, such as $\mathrm{U}_{3} \mathrm{O}_{8}$ to $\mathrm{UF}_{6}$ conversion and LEU fuel fabrication, have remained relatively constant in nominal dollar terms, so these costs have been decreasing in constant dollars.

For the reference value, we assume that the uranium price will recover to $\$ 25 / \mathrm{lb}$ of $\mathrm{U}_{3} \mathrm{O}_{8}$ in 1999 dollars by the year 2050. The lower end of the price range assumes that uranium will

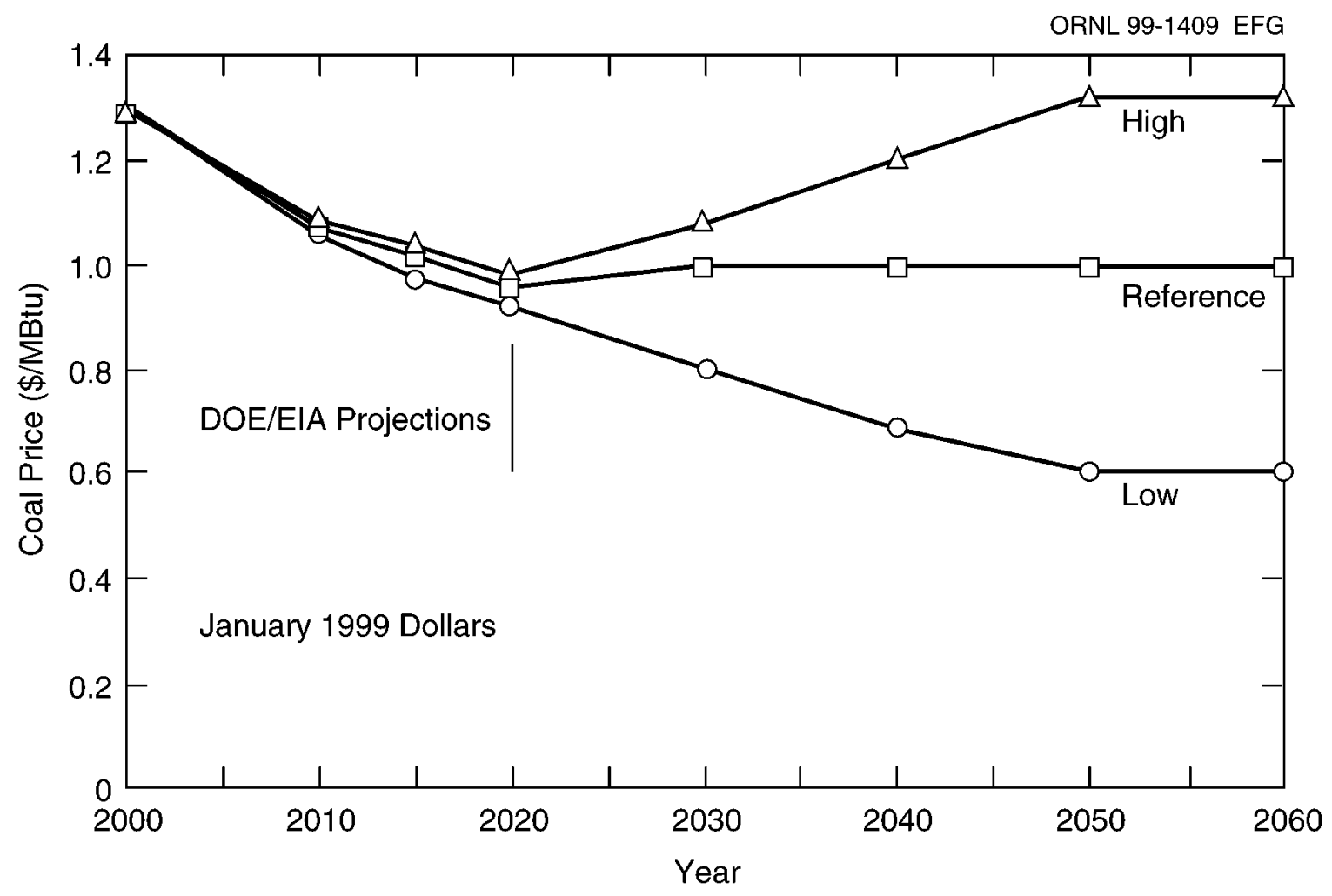

Fig. 3. Coal price projections. 


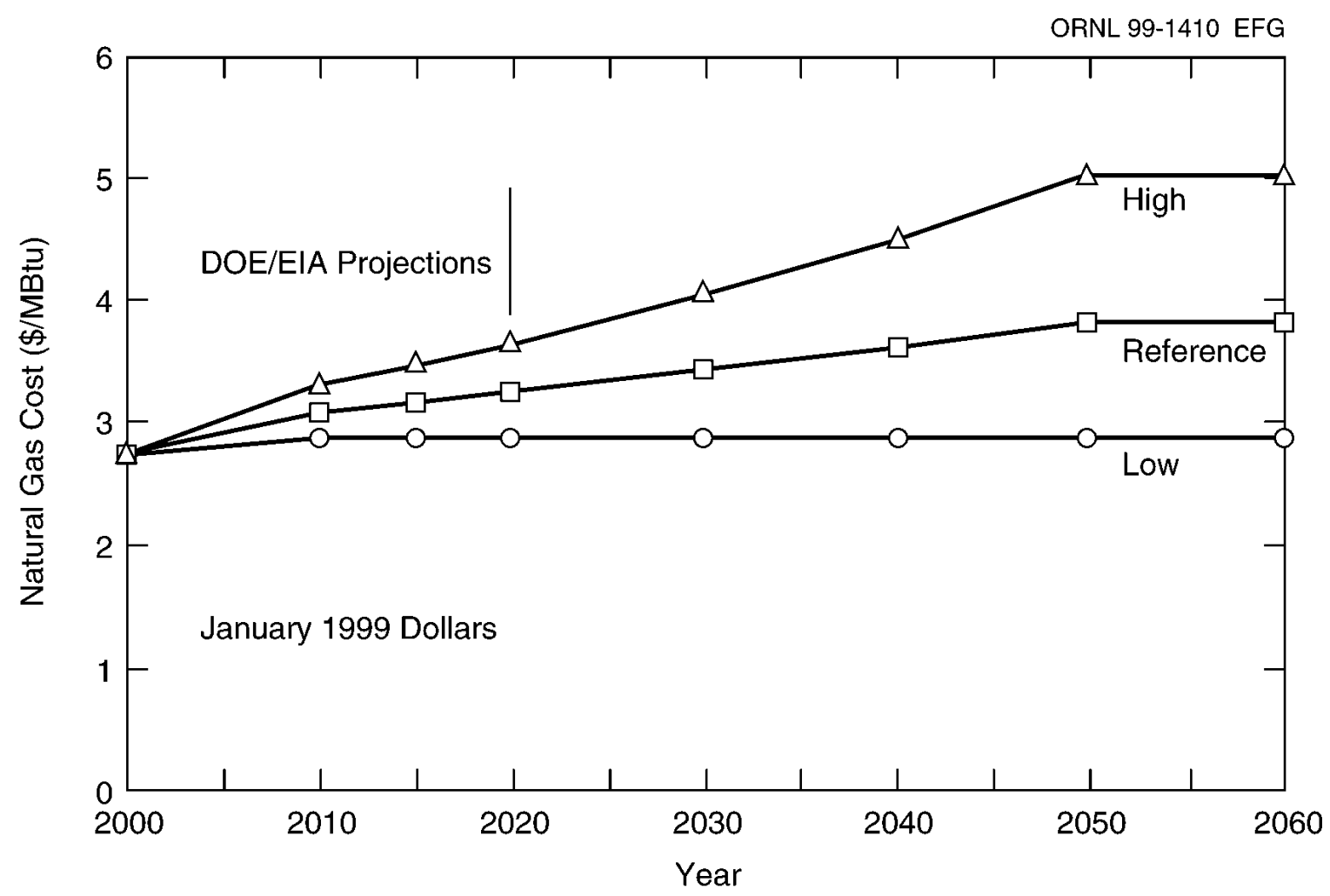

Fig. 4. Natural gas cost projections.

recover from the depressed prices of today, and it will be economic to open new mines but that new ore finds and mining technology improvements will provide an adequate supply of uranium at $\$ 15 / \mathrm{lb}$ of $\mathrm{U}_{3} \mathrm{O}_{8}$. The price of $\$ 145 / \mathrm{lb}$ of $\mathrm{U}_{3} \mathrm{O}_{8}$ at the high end of the range assumes a large nuclear power expansion to meet the national energy needs with increased demand and limited supply driving up the uranium price. The high-end price is limited by the cost of fueling an ALWR with plutonium as discussed below. The other nuclear fuel commodity prices include fuel conversion, enrichment, and fuel fabrication. The reference prices shown in Table 10 are near today's levels. The low-end of the range assumes technology and productivity advances between now and 2050. The high-end of the range assumes moderate price increases from current market values.

The upper end of the range for LWR nuclear fuel cycle costs is limited by the advent of plutonium thermal recycle. Fabricated MOX (uranium and plutonium) fuel for LWRs is being offered at $\$ 3200 / \mathrm{kg}$ of HM. ${ }^{31}$ Although it is not entirely clear what this cost includes, it is assumed that it includes the recovery and storage charge for the plutonium used in the assembly, accounting for approximately $\$ 1800 / \mathrm{kg}$ of HM and about $\$ 1400 / \mathrm{kg}$ of HM for the fabrication of the MOX fuel assembly. At such a price, the LEU and MOX fuel cycle costs for the ALWR model used for this study are equal at a uranium price of about $\$ 145 / \mathrm{lb}$ of $\mathrm{U}_{3} \mathrm{O}_{8}$, assuming an optimum tails assay, with all other parameters held at their reference values. It is also possible that in 2050 the weapons-derived plutonium may still be used for MOX fuel. The use of this material may provide a cap on the cost of MOX fuel. A range for ALWR MOX fuel costs of from $\$ 2000$ to $\$ 4000 / \mathrm{kg}$ of HM is shown. The low-end of the range assumes learning in an expanding industry, technological advances, and possible continuing use of weapons-derived plutonium as nuclear weapon stockpiles are reduced by today's nuclear powers. The high-end of the range 
assumes recognition of as yet undefined costs. This high-end cost was used to estimate the upper range for ALWR fuel cycle costs.

If plutonium recycle in thermal reactors becomes a reality, the advent of the ALMR fast reactor should follow. This concept is limited by economic and proliferation questions. The ALMR fuel recycle cost shown is based on the reactor being started up and refueled by recycled plutonium from it and other ALMRs. The range in costs shows a considerable uncertainty in ALMR fuel recycle costs. The range assumes a $10 \%$ reduction in costs from technology advances for low-end costs and a 50\% increase in the high-end costs, reflecting unrecognized costs and the need to start some plants on reprocessed LWR fuel.

The current waste disposal charge on nuclear electric production is $1 \mathrm{mill} / \mathrm{kWh}$. A nominal range of from 0.5 to $1.5 \mathrm{mills} / \mathrm{kWh}$ is assumed for this study. Geologic repository storage of spent fuel is the assumed technology. Concepts for separating and transmuting the long-lived fission product and actinide wastes in spent fuel are being studied as a means of enhancing the acceptability of geologic storage. The use of such concepts might begin in the 2030 time frame and use accelerators or subcritical reactors as neutron sources. Detailed cost estimates are not yet available for these technologies and their economic impact on nuclear high-level waste disposal costs.

\subsection{DECOMMISSIONING COSTS}

Decommissioning costs for all plants were assumed to be negligible except those for nuclear fission and fusion. Decommissioning costs for LWR plants are currently estimated at $\$ 400 \mathrm{M}$ or more. ${ }^{32}$ The advanced plants should not cost this much to decommission because the designs are simpler. The ALWR fission plant decommissioning costs were assumed to be $\$ 300 \mathrm{M}$ in 1999 dollars. The ALMR consists of three smaller units. The cost for the ALMR decommissioning $(\$ 680 \mathrm{M})$ is based on proponent estimates, escalated to 1999 dollars.

Decommissioning costs for the fusion plants were assumed to be the same as those for the ALWR scaled for plant size.

\subsection{EMISSIONS ABATEMENT COSTS}

If the emissions of $\mathrm{CO}_{2}$ and other greenhouse gases represent a real global environmental threat, reduction or elimination of these releases will be imperative. Based on current technology, the cost of chemically extracting $\mathrm{CO}_{2}$ from coal-fired plant flue gases is very expensive with estimates ${ }^{33-35}$ in the range of $\$ 20 /$ tonne of $\mathrm{CO}_{2}$ extracted to more than $\$ 70 /$ tonne depending on the power plant and the source of the information. This is in addition to the cost of transportation and the disposal or storage. Recovered $\mathrm{CO}_{2}$ can be stored underground in saline deposits, in old oil or gas wells (possibly enhancing oil recovery), and in the deep ocean. With current absorption technology, capture from the flue gases requires significant energy, thereby reducing the plant's net electrical output. Energy penalties today ${ }^{34}$ are estimated at $27 \%-37 \%$ for conventional coal, $15 \%-24 \%$ for natural gas combustion, and $13 \%-27 \%$ for coal gasification. Future improvements in capture technology and increased scale of operation should reduce the cost of capture and sequestration significantly. Projected technologies ${ }^{34}$ should reduce these energy penalties to about $15 \%$ for conventional coal, $10 \%$ for natural gas combustion, and $9 \%$ for coal gasification. For the coal-burning plants in this study (PC-FGD and PFBC plants), a reference energy penalty of $15 \%$, with a range of $12 \%-18 \%$, is assumed. This means that a coal-fired power station that typically produces $1200 \mathrm{MW}(\mathrm{e})$ will only have $1020 \mathrm{MW}(\mathrm{e})$ for sale because it is using $180 \mathrm{MW}(\mathrm{e})$ internally for $\mathrm{CO}_{2}$ capture. In the case of the GCC and CCCT plants, a reference energy penalty of $10 \%$ is assumed with a range of $8 \%-12 \%$. In addition, a reference cost of $\$ 10 /$ tonne of $\mathrm{CO}_{2}$ (range $=\$ 5$ to $\$ 15 /$ tonne) is assumed for other costs associated with the capture and for transportation and ultimate storage of the $\mathrm{CO}_{2}$. 


\section{RESULTS}

Table 11 shows the baseline estimated levelized COE in mills per kilowatt hour, including the estimated cost of $\mathrm{CO}_{2}$ capture and disposal for each concept for plant start-up in the year 2050. The capital-related portion of the COE is proportional to the capital investment cost and inversely proportional to the plant capacity factor. It is the largest component of $\mathrm{COE}$ for all technologies except the natural-gas-fired CCCT where the cost of the fuel (natural gas) is the dominant cost component. The calculated COE ranges are also tabulated in Table 11. The high end of the unit $\mathrm{COE}$ range was computed assuming the most pessimistic of the cost uncertainties for each cost component. The low end of the cost range assumes that the most optimistic parameters prevail.

Except for the capacity factor and plant size, uncertainty ranges were not applied to the fusion cost estimates. The range shown in Table 11 for the fusion plants assumes a 70\% capacity factor to obtain the high-end costs and a 90\% capacity factor for the low-end costs.

Coal-Fired Plants. The transition from present day PC-FGD plants to future PFBC plants with carbon sequestration is shown in Fig. 5. The decline in COE for the PC-FGD between 1999 and 2050 is a result of falling coal prices. The transition to the PFBC as the preferred means of burning coal for electric power produces a further cost reduction of about 5-7 mills $/ \mathrm{kWh}$. Even when the fuel cost uncertainty is included, the overall COE range for the PFBC is about $30-45$ mills $/ \mathrm{kWh}$. If capture of $\mathrm{CO}_{2}$ from the flue gas and sequestration are included, the $\mathrm{COE}$ range at reference parameters increases by about $19 \mathrm{mills} / \mathrm{kWh}$, bringing the overall COE range with carbon sequestration to about 40-74 mills $/ \mathrm{kWh}$.

Coal Gasification. The COE associated with the GCC plant is shown in Fig. 6. As with the PFBC, the COE range is fairly insensitive to coal price. When the coal price uncertainty range is included, the overall uncertainty range (without $\mathrm{CO}_{2}$ capture and disposal) is about $35-53 \mathrm{mills} / \mathrm{kWh}$, whereas the COE range is $37-50 \mathrm{mills} / \mathrm{kWh}$ if the reference coal price is assumed throughout. If the cost of carbon capture and sequestration is included, the reference $\mathrm{COE}$ is increased by about $15 \mathrm{mills} / \mathrm{kWh}$ to about $59 \mathrm{mills} / \mathrm{kWh}$, and the overall COE range becomes $42-76$ mills $/ \mathrm{kWh}$.

Natural Gas. The use of natural gas also includes potential greenhouse gas problems. Both methane (principal component of natural gas) and $\mathrm{CO}_{2}$ formed by natural gas burning are greenhouse gases. Release of methane to the atmosphere would occur if there was leakage from the system or incomplete combustion. A methane penalty was not assessed in this study. The COE associated with the natural-gas-fired CCCT plant is shown in Fig. 7. The present day (year 1999) costs are based on a $\$ 2.75 / \mathrm{MBtu}$ natural gas price. By 2050 , the natural gas price is expected to increase to the $\$ 3.85 / \mathrm{MBtu}$ reference price, but the plant heat rates are expected to improve, producing a COE range of about $31-43 \mathrm{mills} / \mathrm{kWh}$ at the reference gas price. When the natural gas price uncertainty is included, the overall COE uncertainty range without carbon sequestration is about $26-52 \mathrm{mills} / \mathrm{kWh}$. If the energy penalty and cost of carbon disposal are included, the reference COE increases by about 9 mills/kWh, and the overall COE uncertainty range becomes 30-65 mills/kWh.

Nuclear Fission. The COEs for the ALWR and ALMR nuclear power plants are shown in Fig. 8. The range of costs for nuclear fission includes the assumption that it will be an acceptable future option. The upper cost ranges for the ALWR and ALMR were found to be nearly equal at about 62 mills/kWh. The ALWR high-end COE was calculated assuming a MOX fuel cost of $\$ 4000 / \mathrm{kg} \mathrm{HM}$ or LEU fuel with a uranium cost of $\$ 190 / \mathrm{lb}$ of $\mathrm{U}_{3} \mathrm{O}_{8}$. The COE at reference parameters is about $45 \mathrm{mills} / \mathrm{kWh}$ for the ALWR and about $51 \mathrm{mills} / \mathrm{kWh}$ for the ALMR. The COE range at reference fuel prices is about $40-50$ mills/kWh for the ALWR and about 
Table 11. Levelized COE

\begin{tabular}{|c|c|c|c|c|c|c|c|c|c|}
\hline & \multicolumn{9}{|c|}{ COE (1999\$ mill/kWh) } \\
\hline & \multirow[b]{2}{*}{ PC-FGD } & \multirow[b]{2}{*}{ PFBC } & \multirow[b]{2}{*}{$\mathrm{CCG}$} & \multirow[b]{2}{*}{$\mathrm{CCCT}$} & \multirow[b]{2}{*}{ ALWR } & \multirow[b]{2}{*}{ ALMR } & \multirow[b]{2}{*}{ Wind } & \multicolumn{2}{|c|}{ Magnetic fusion } \\
\hline & & & & & & & & Aries-RS & Aries-ST \\
\hline Capital & 26.7 & 22.5 & 26.5 & 8.8 & 29.7 & 30.6 & 24.7 & 72.1 & 79.5 \\
\hline O\&M & 8.5 & 7.2 & 9.4 & 4.5 & 8.6 & 10.4 & 4.6 & $9.0^{c}$ & $9.0^{c}$ \\
\hline Fuel & 9.4 & 8.1 & 8.1 & 26.6 & 5.6 & 8.8 & & $5.4^{d}$ & $3.8^{d}$ \\
\hline Decommissioning & & & & & 0.8 & 1.5 & & 0.9 & 0.9 \\
\hline Total COE & 64.6 & 50.8 & 59.3 & 48.6 & 44.7 & 51.3 & $29.3^{b}$ & 87.4 & 93.2 \\
\hline Range & $47-82$ & $39-74$ & $42-76$ & $30-65$ & $38-62$ & $45-62$ & $18-62$ & $69-99 f$ & $74-106^{f}$ \\
\hline
\end{tabular}

${ }^{a}$ Cost of $\mathrm{CO}_{2}$ sequestering or emissions charge.

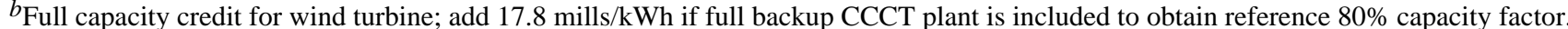

${ }^{c}$ From procedure used to calculate O\&M costs for passively safe ALWRs.

$d_{\text {Includes blanket replacement. }}$

${ }^{e}$ No separate provision made for target replacement, included with O\&M costs in source document.

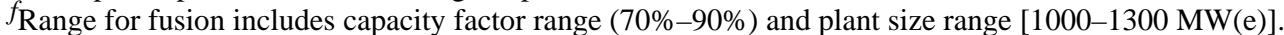




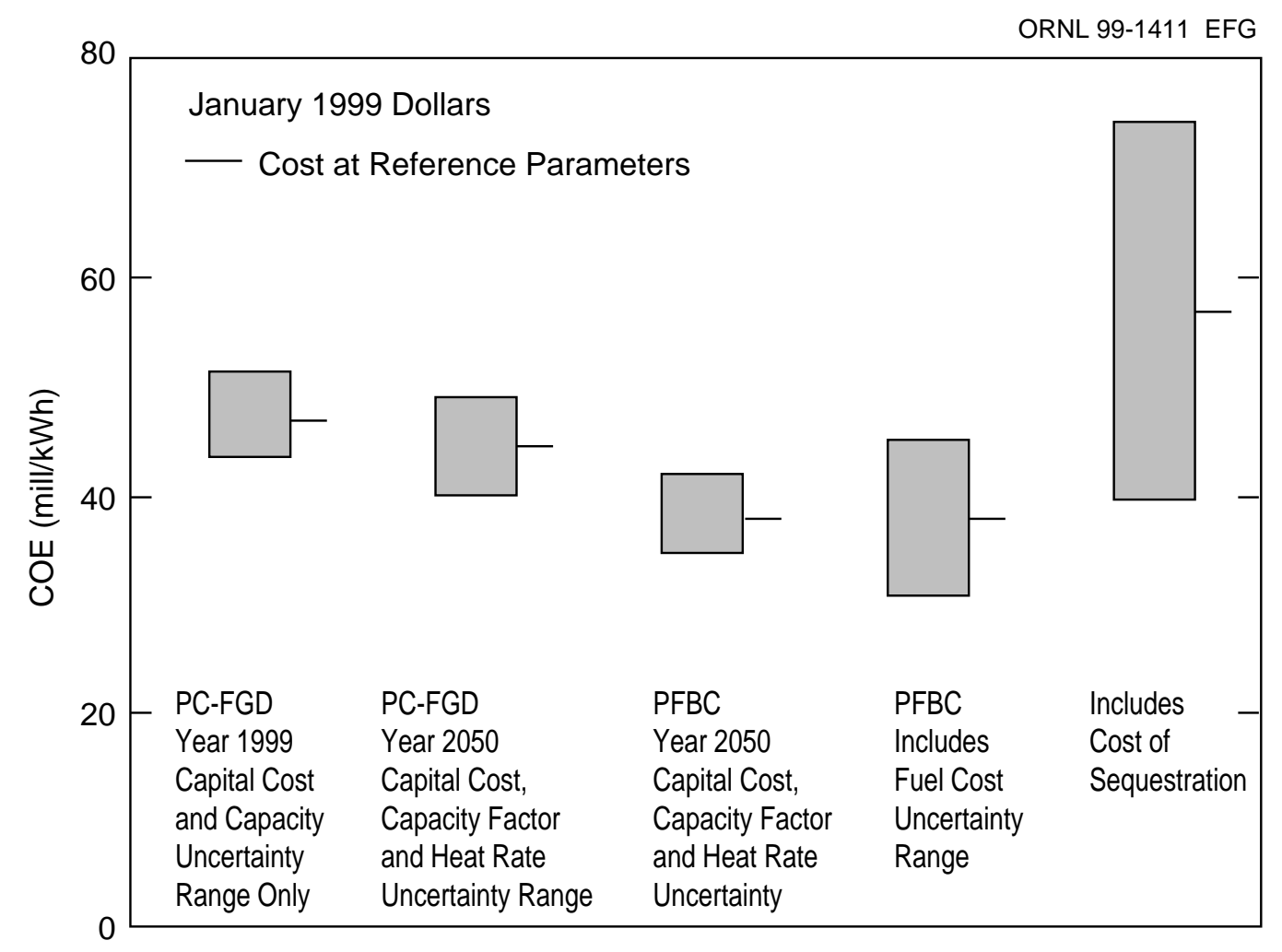

Fig. 5. Range of COE for coal-burning plants.

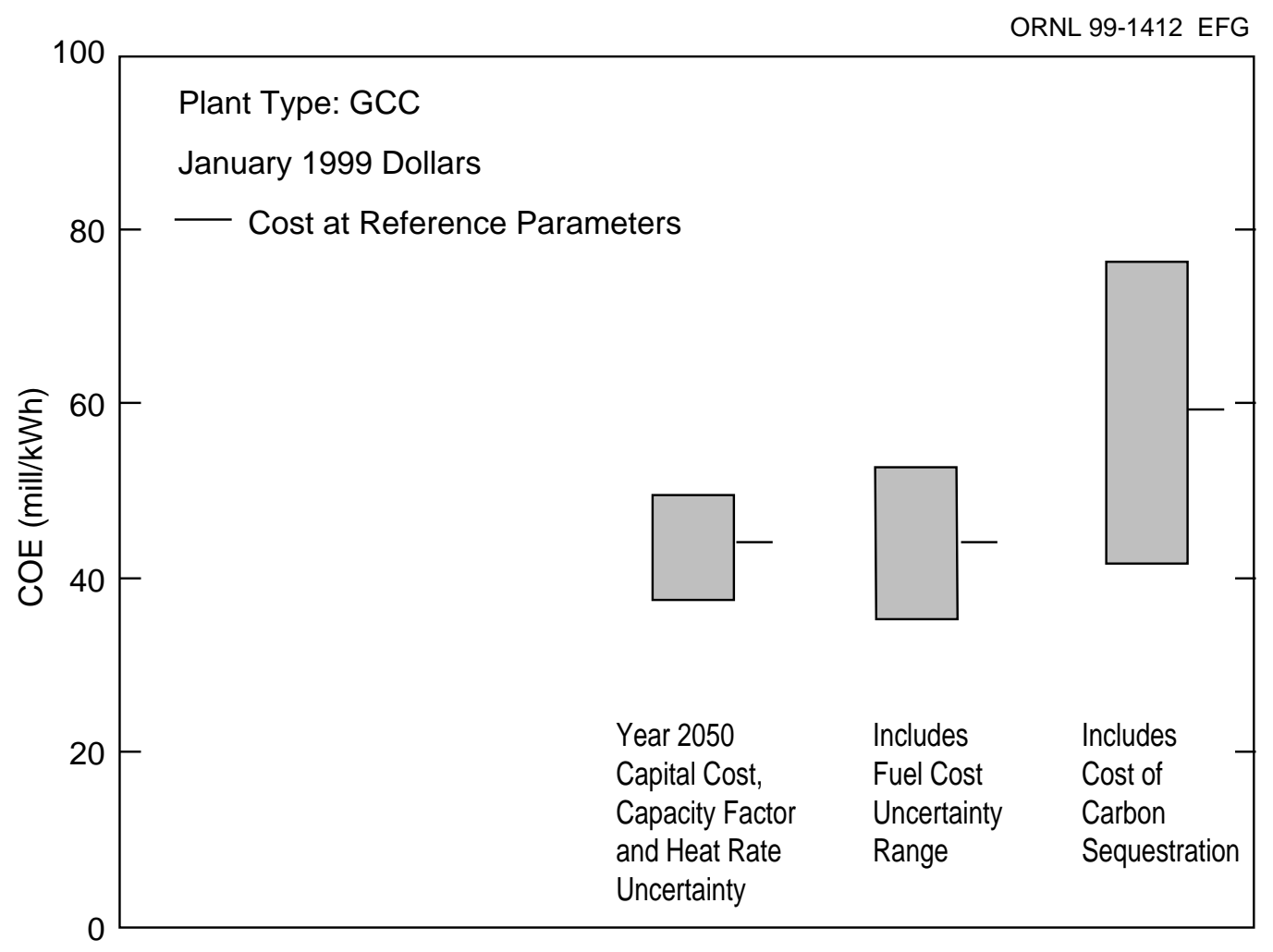

Fig. 6. Range of COE for coal gasification plants. 


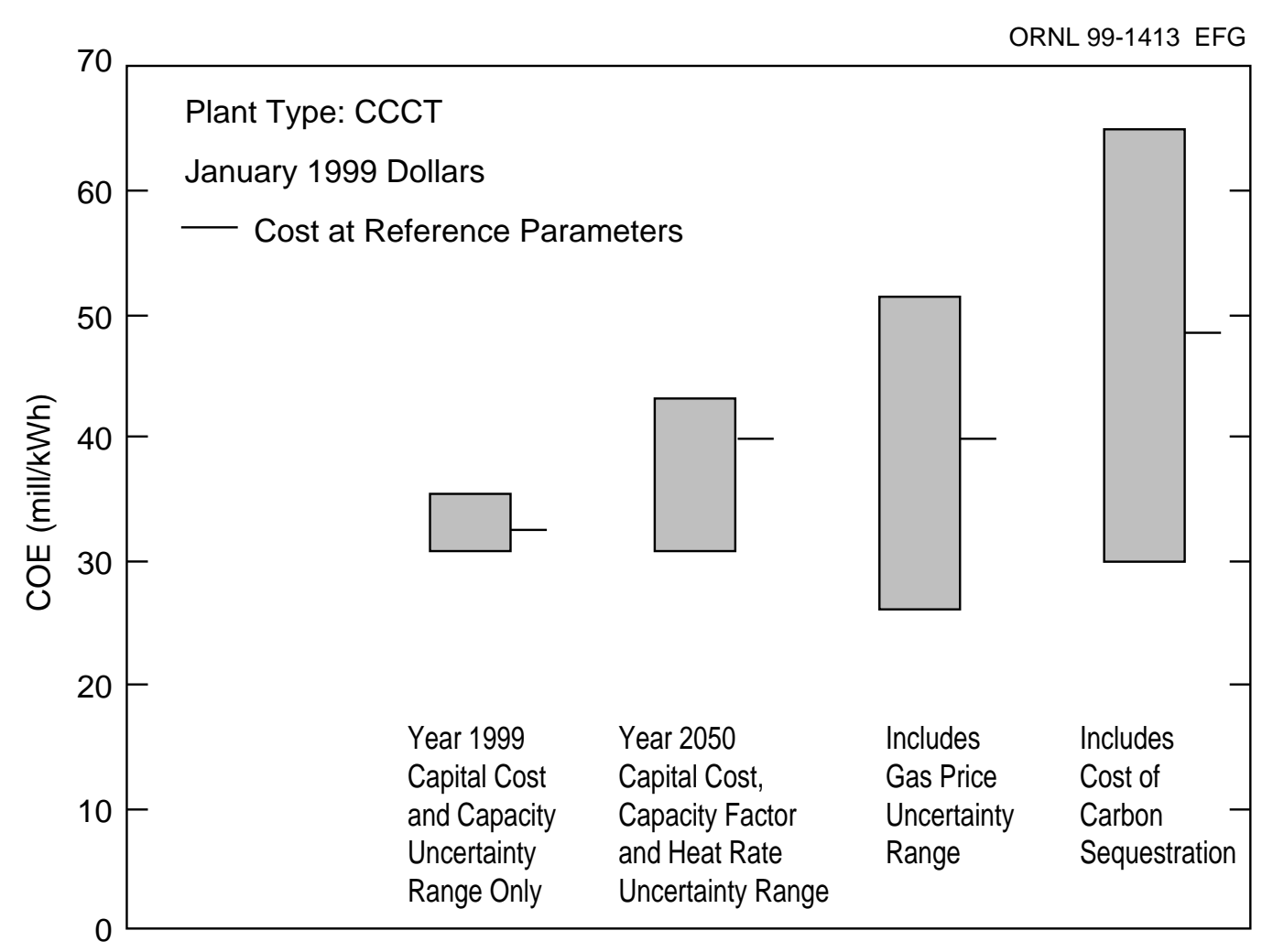

Fig. 7. Range of COE for natural gas.

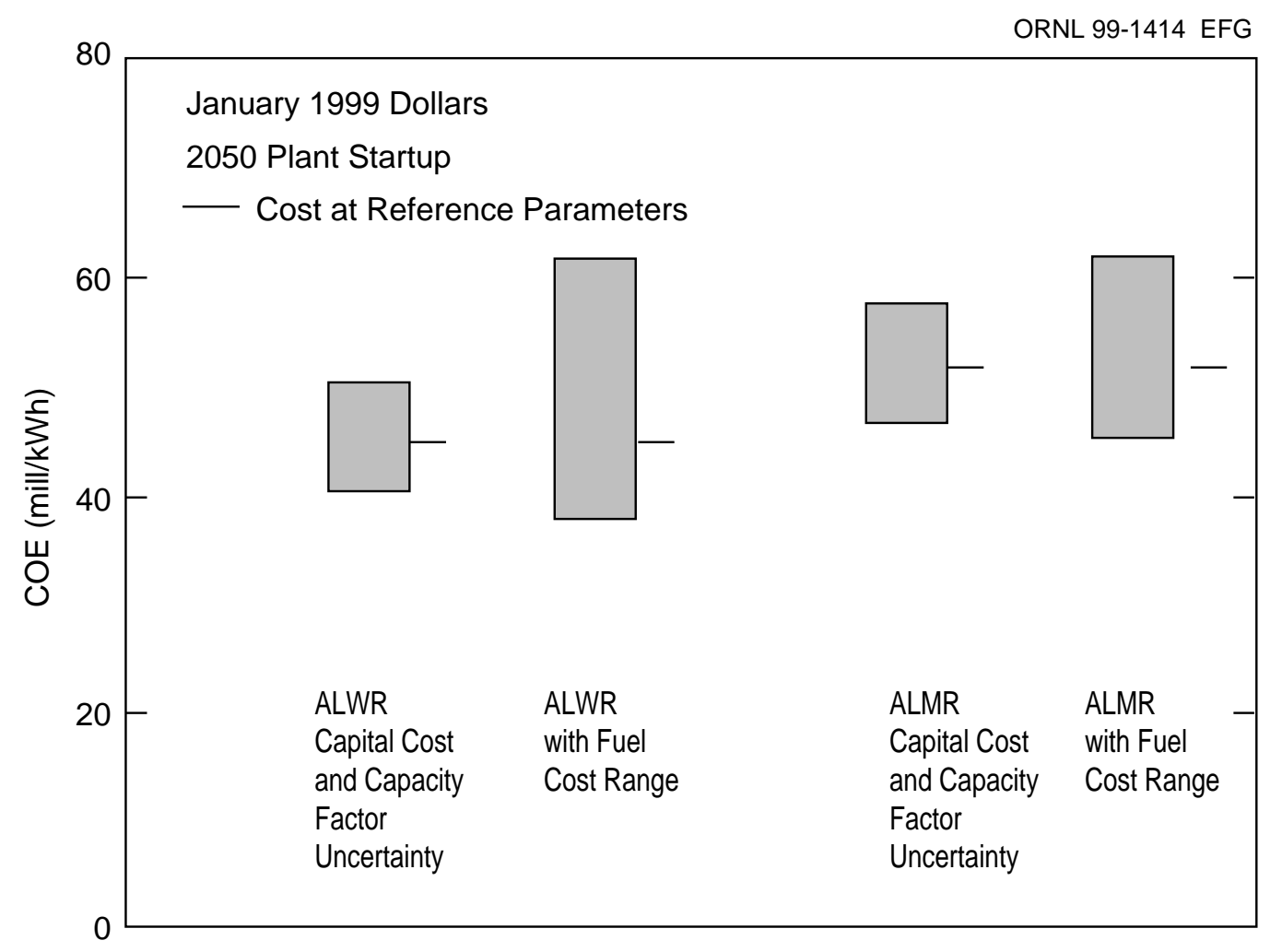

Fig. 8. Range of COE for nuclear plants. 
46-57 mills/kWh for the ALMR. If the fuel cost range is included, the overall COE range is about 38-62 mills/kWh for the ALWR and about 45-62 mills/kWh for the ALMR.

Wind. The COE associated with wind power is shown in Fig. 9. The year 2000 cost range assumes some technological advancements as given in the Renewable Energy TC document. ${ }^{16}$ Further advancements are projected. The resulting COE range for 2050 plant startup and the reference $35 \%$ capacity factor is about $23-35 \mathrm{mills} / \mathrm{kWh}$ with a reference COE of about $29 \mathrm{mills} / \mathrm{kWh}$. If the assumed range in capacity factor is included, the overall COE range becomes about $18-50$ mills $/ \mathrm{kWh}$.

The previous COE estimates assume that wind can be counted on for its full capacity on the electric grid. This is probably so for wind turbine penetrations up to $5 \%$ of the system capacity. ${ }^{16}$ However, wind is intermittent; for large wind power penetrations, additional backup capacity may have to be built or electric energy storage devices installed. The amount of storage capacity or backup needed depends on the overall power system characteristics and is beyond the scope of this study.

The final bar in Fig. 9 assumes that a full-size CCCT plant is installed as backup for the wind turbine capacity. The CCCT operates whenever the wind turbine station does not operate. If the wind turbine has a $35 \%$ capacity factor and if an $80 \%$ overall capacity factor is to be achieved, the CCCT plant is assumed to operate an equivalent $45 \%$ of the time. The wind turbine facility thus acts as a fuel (and carbon sequestration cost) saver for the CCCT plant. The overall COE range for this combined plant is about 30-64 mills/kWh with a 47-mills/kWh COE at reference parameters. Because some wind capacity will be able to be credited, the COE range for wind turbines will lie somewhere between the results shown on the final two bars in Fig. 9.

Fusion. The COE range for fusion power plants is shown in Fig. 10. The first bar shows the calculated COE range between the ARIES-RS and the ARIES-ST at the reference $80 \%$

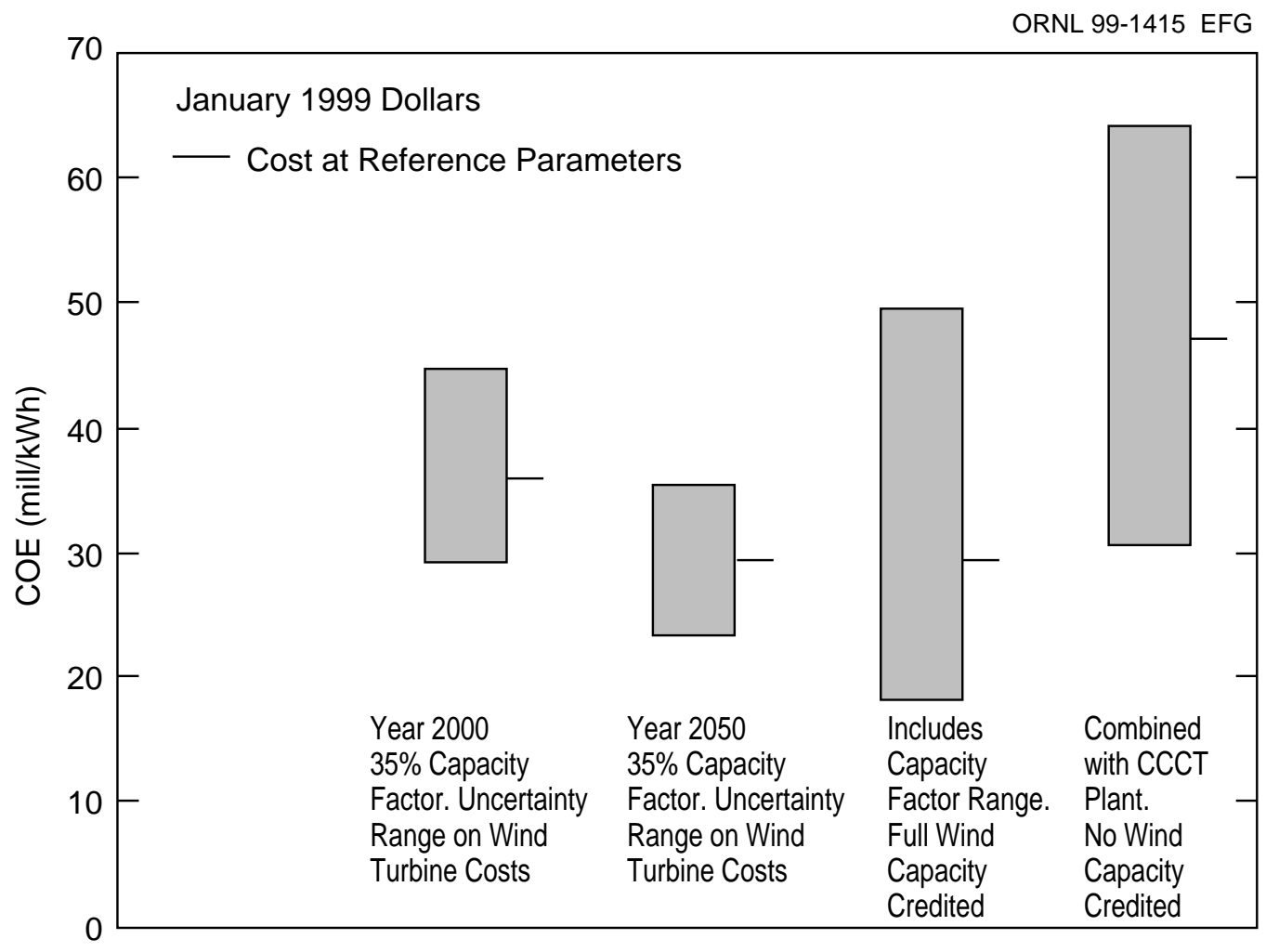

Fig. 9. Range of COE for wind. 


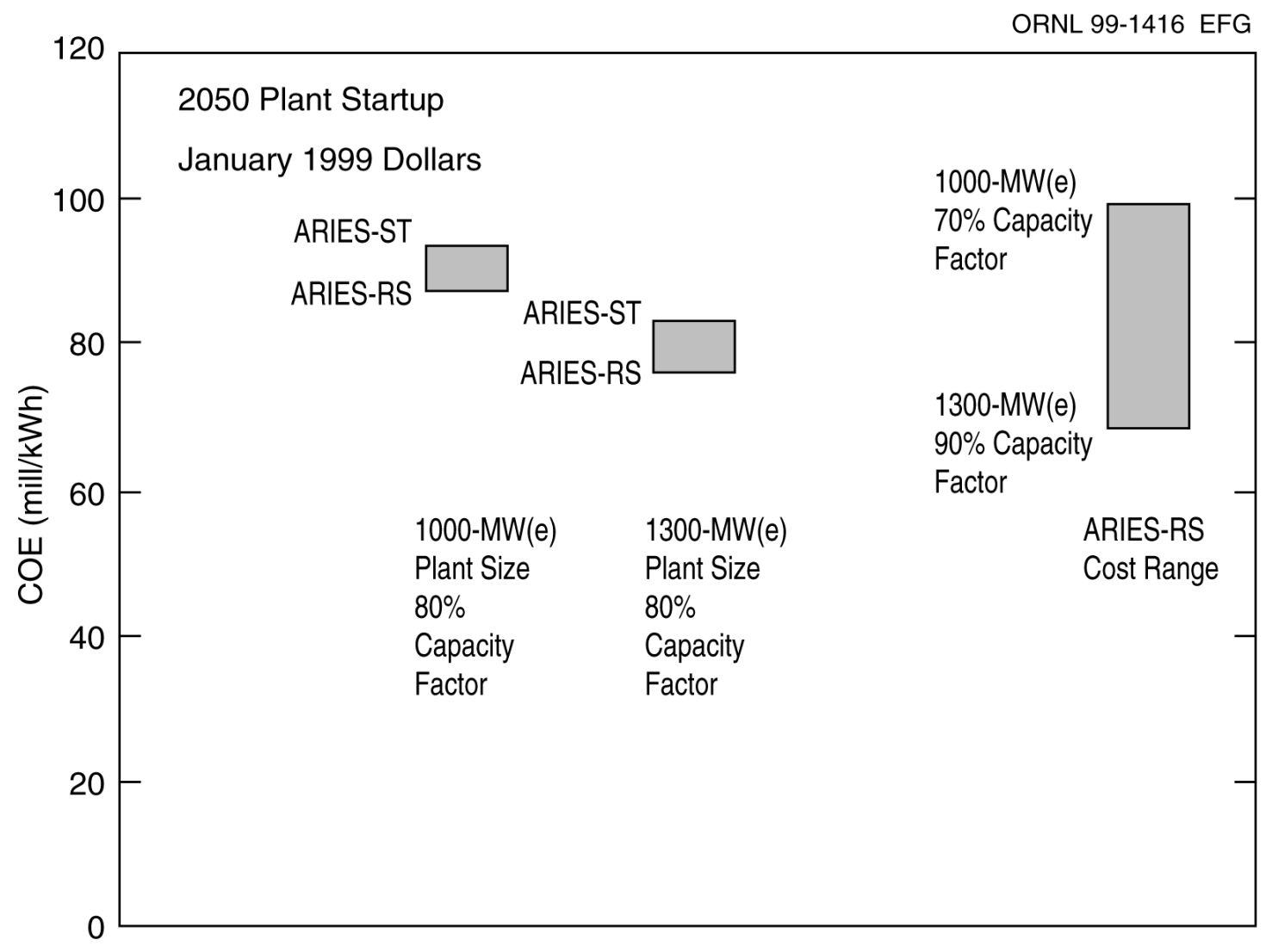

Fig. 10. Range of COE for fusion power plants.

capacity factor. The second bar shows the effect of increasing the plant size to $1300 \mathrm{MW}(\mathrm{e})$. It is estimated that the COE is reduced by about $10 \mathrm{mills} / \mathrm{kWh}$ by this $30 \%$ increase in unit size. The final bar shows the COE range with uncertainty for the ARIES-RS. The high end of the range assumes a 1000-MW(e) plant size and 70\% capacity factor. The low end of the range assumes a $1300-\mathrm{MW}$ (e) plant size and $90 \%$ capacity factor. This COE range of approximately $70-100 \mathrm{mills} / \mathrm{kWh}$ is the reference cost range for fusion for this study.

\section{DISCUSSION OF RESULTS}

The COE ranges for each of the concepts considered in this study are shown in Figs. 11 and 12. Figure 11 excludes the cost associated with carbon sequestration, whereas Fig. 12 includes these costs. The COEs at reference parameters are marked for each concept.

The COE ranges for the coal-burning technologies assume that the PC-FGD will be phased out and replaced by the PFBC by the 2050 startup date considered here. If natural gas supplies remain adequate at the prices assumed in this study, then natural gas will remain a competitive option well into the future.

The effect on the COE for fossil-fired plants of the need to extract and permanently dispose of $\mathrm{CO}_{2}$ from the flue gas can be significant. Comparing the first three bars from Figs. 11 and 12 shows an increase in the reference COE of about 9-19 mills/kWh due to carbon sequestration. The cost is less for natural gas combustion and greatest for coal burning. The high end of the uncertainty range is increased by about $14-30 \mathrm{mills} / \mathrm{kWh}$, and the low-end costs are increased by about $4-9$ mills/kWh. 


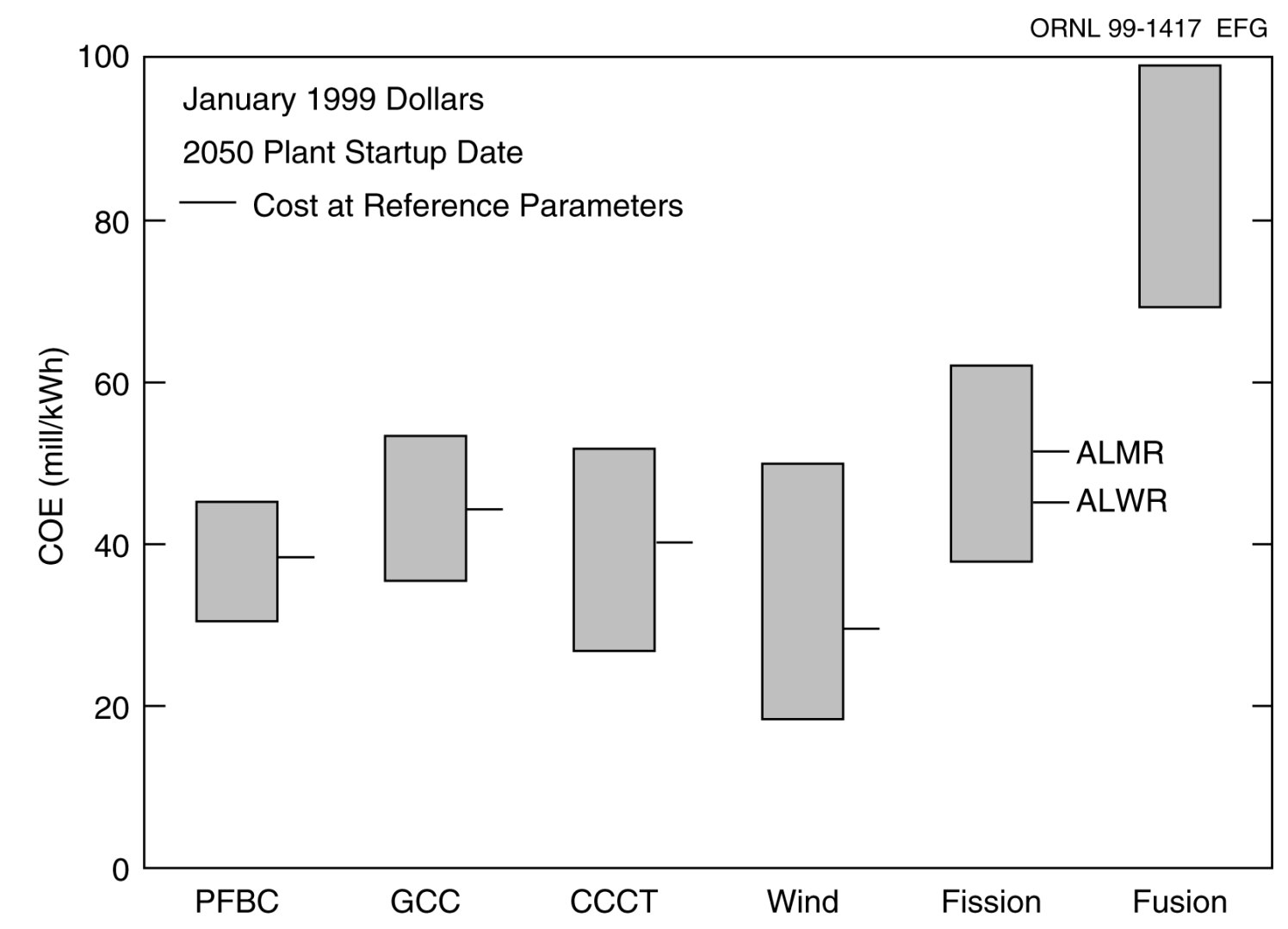

Fig. 11. Range of $\mathrm{COE}$ for concepts without carbon sequestration.

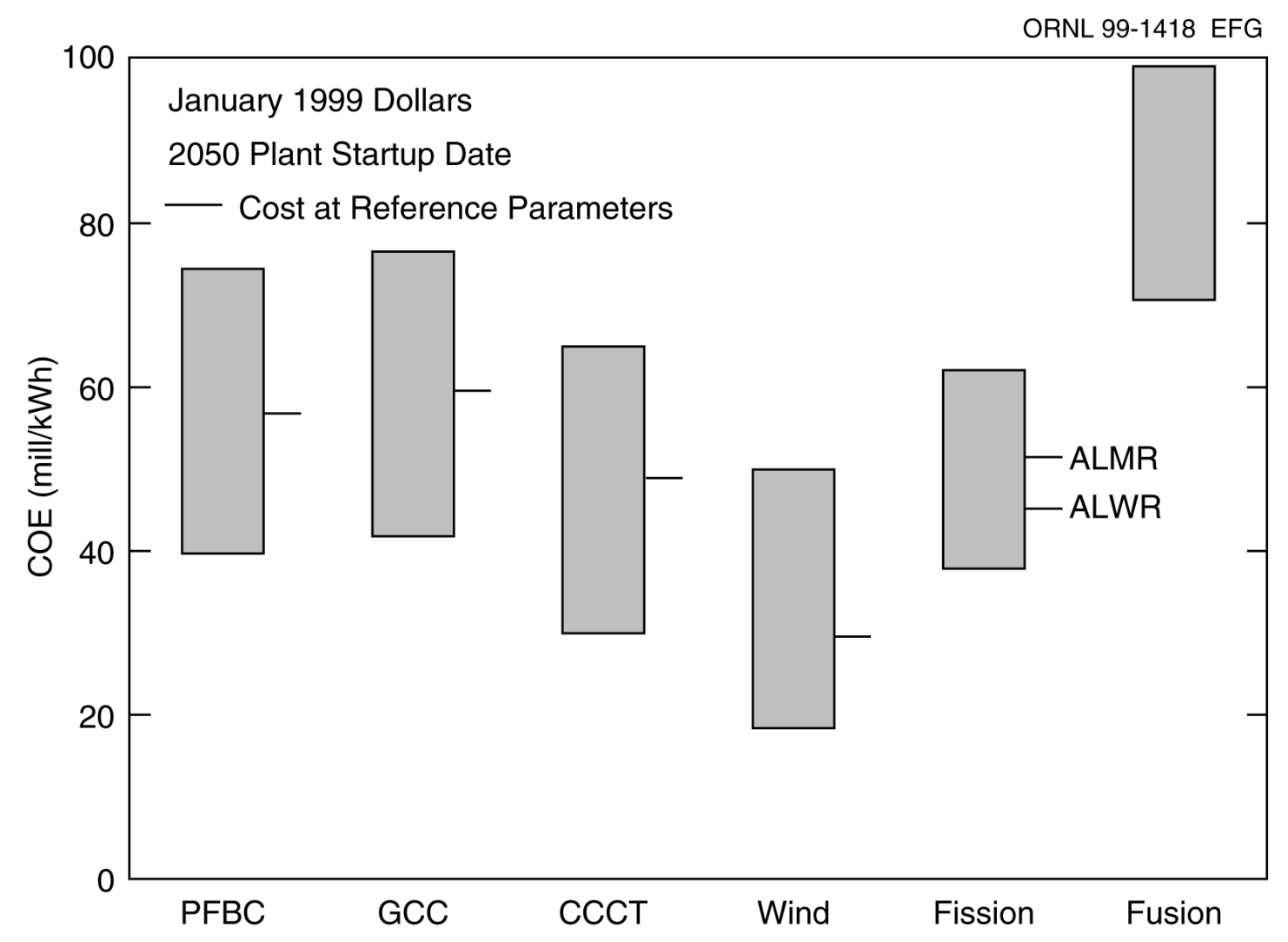

Fig. 12. Range of COE for concepts including carbon sequestration. 
Wind turbines will be competitive in areas where they can operate at moderate to high capacity factors. However, wind is intermittent, and the added cost of electric energy storage or the use of gas turbines as backup will raise the COE for this technology if large grid penetrations are to be achieved.

Nuclear fission should remain as a future option based on its projected economics. Questions of safety and public acceptance will have to be resolved before nuclear fission's full potential can be achieved.

The cost ranges shown for fusion in Figs. 11 and 12 use the ARIES-RS at 70\% capacity factor and 1000-MW(e) plant size for the high end of the COE range and 90\% capacity factor and 1300-MW(e) plant size at the low end. There is, of course, a great deal of uncertainty here, and the numbers shown should be used with care. Capital investment is the principal cost driver for fusion. The fusion island is a large cost component whose cost is relatively insensitive to plant size; thus, fusion economics improve significantly for larger sized plants. As electric grids become larger, the system penalties for large unit sizes will diminish, and coal and nuclear fission plants will also become larger. The French currently are proposing a series of 1750-MW(e) nuclear units ${ }^{36}$ that they think will be more economical than current nuclear plants. The large recirculating power needs for fusion also drive up the capital investment because the plant must be sized to produce more power than it actually sells. Fossil energy plants with sequestration also suffer from the large recirculating power needs, however, because their fixed costs (capital investment and fixed O\&M) are less than for fusion; the effect on COE is less for the same recirculating power fraction.

The results from this study are summarized in Fig. 13. Here the COE range for fusion is compared with the COE range for the alternatives using different sets of assumptions. For

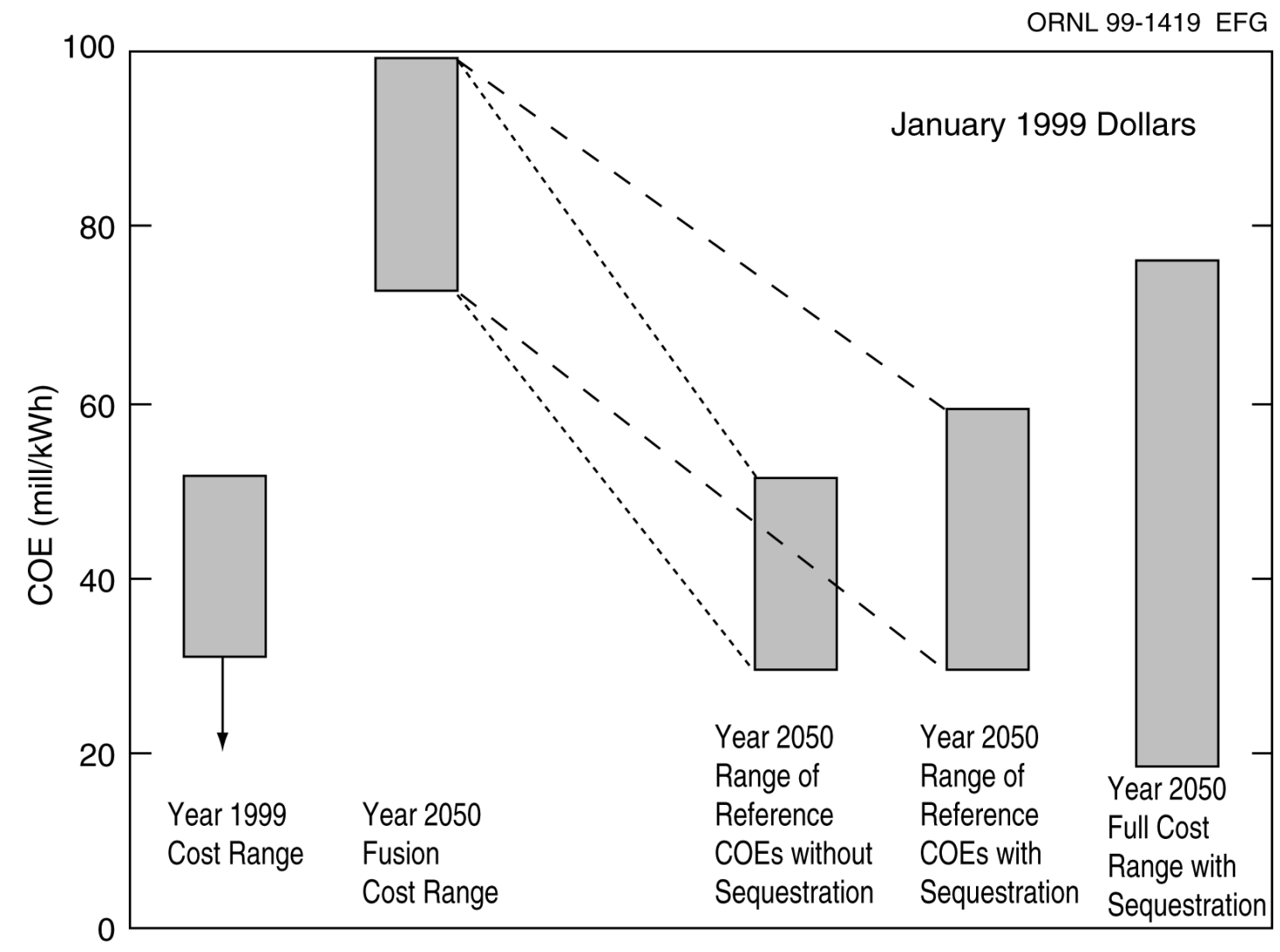

Fig. 13. Cost range summary. 
perspective, the COE range (including uncertainty) is also shown for plants that could be built today.

Based on full cost recovery, the COE from a plant built today should be about 30-50 mills/kWh. However, since deregulation, some electricity is being sold at its marginal cost of production, which does not include capital recovery. This is indicated by the downward pointing arrow on the first bar in Fig. 13.

For 2050 plant startup, the COE range at reference parameters is still $30-50$ mills/kWh if power producers are not required to sequester $\mathrm{CO}_{2}$. Wind power provides the low point in this range. If carbon sequestration is required, the $\mathrm{COE}$ range based on reference parameters becomes about 30-59 mills $/ \mathrm{kWh}$ or about $18-76 \mathrm{mills} / \mathrm{kWh}$, if the full range of cost parameter uncertainties is included. The low-end cost includes wind generation with full credit for the capacity on the grid. If wind is excluded, the low end is about $30 \mathrm{mills} / \mathrm{kWh}$.

\section{CONCLUSION}

If fusion is to become a viable electric energy supplier in the future, ways must be found to reduce its costs. Technology advancements and cost reductions are projected for the technologies that fusion will be competing against when it is ultimately deployed in the middle of the next century. In addition, the costs of fossil fuels are declining instead of increasing as was projected in the past. The COE from renewable energy sources such as wind is also being reduced, and it can be a viable contender in the next century.

The COE from the alternatives to fusion for a plant starting operation in 2050 should remain in the 30- to 50-mills $/ \mathrm{kWh}$ range if capture of $\mathrm{CO}_{2}$ and its disposal are not required. If carbon sequestration is required, this range should increase to 30-60 mills $/ \mathrm{kWh}$ or as high as 76 mills $/ \mathrm{kWh}$ if the full range of cost parameter uncertainties is considered.

The COE for fusion is generally above the range for the alternatives except for the high end of the alternative uncertainty. Fusion costs will have to be reduced and/or alternative concepts devised before fusion will become competitive. Fortunately, there are routes to achieve this goal, such as building larger plants. 


\section{REFERENCES}

1. Electric Power Annual 1998 Volume 1, U.S. Department of Energy, Energy Information Administration, DOE/EIA-0348 (98)/1.

2. Annual Energy Outlook 1998, U.S. Department of Energy, Energy Information Administration, DOE/EIA-0383 (1999), December 1998.

3. U.S. Coal Reserves: 1997 Update, U.S. Department of Energy, Energy Information Administration, DOE/EIA-0529 (97), February 1999.

4. Nuclear Energy Cost Data Base: A Reference Data Base for Nuclear and Coal Fired Power Plant Power Generation Cost Analysis, U.S. Department of Energy, Office of Nuclear Energy, DOE/NE-0095, 1988.

5. J.G. Delene and C.R. Hudson, Cost Estimate Guidelines for Advanced Nuclear Power Technologies, ORNL/TM-10071/R3, Lockheed Martin Energy Systems, Inc., Oak Ridge National Laboratory, 1993.

6. $\mathrm{TAG}^{\mathrm{TM}}$ Technical Assessment Guide Electricity Supply-1993, Electric Power Research Institute, EPRI TR-102276-ViR7, June 1993.

7. J. R. Redding and P. R. MacGregor, "Advanced Nuclear Plants: Meeting the Economic Challenge," presented at the American Nuclear Society 1993 Winter Meeting, San Francisco, California, 1993.

8. G. A. Davis et al, "Lessons Learned from Design Certification of System $80+{ }^{\mathrm{TM}}$," pp. 277-281 in Proceedings of the Ninth Pacific Basin Nuclear Conference, Sydney Australia, 1994.

9. J. D. Mottley, "Electricity Generation Cost Reduction with the AP600 Reactor," presented at the American Nuclear Society 1993 Winter Meeting, San Francisco, California, 1993.

10. Advanced Design Nuclear Power Plants: Competitive Economical Electricity, U.S. Council for Energy Awareness, 1992.

11. B. A. Hutchins, "Economic Acceptance of the ALMR," presented at the American Nuclear Society 1993 Winter Meeting, San Francisco, California, 1993.

12. "Pebble Bed Model Goes Critical Moving ESKOM Closer to Decision," Nucleonics Week, 40(29) (July 22, 1999).

13. Nuclear Fuel, 23(21), 14 (October 19, 1998).

14. "Bright Future—or Brief Flare—for Renewable Energy," Science, 285, 678-680 (1999).

15. "Fact File," Renewable Energy World, 2(3), 135 (May 1999).

16. Renewable Energy Technology Characterizations, A Joint Project of Electric Power Research Institute and Office of Utility Technologies, Energy Efficiency and Renewable Energy, U.S. Department of Energy, EPRI TR-109496, December 1997.

17. Personal communication from R. Miller, University of California-San Diego, to J. G. Delene, Lockheed Martin Energy Systems, Inc., Oak Ridge National Laboratory, July 2, 1999.

18. C. G. Bathke, The ARIES Team, "Systems Analysis in Support of the Selection of the ARIES-RS Design Point,” Fusion Engineering and Design, 38, 59-86 (1997).

19. R. W. Moir, "Inertial Fusion Energy Power Plants Based on Laser or Ion Beams," Proceedings of ICENES' 98 The Ninth International Conference on Emerging Nuclear Energy Systems, Herzila, June 28-July 2, 1998.

20. R. W. Moir et al., "Hylife-II A Molten-Salt Inertial Fusion Energy Power Plant Design-Final Report," Fusion Technology, 25, 5-25 (1994).

21. Vision 21 Strategic Plan and Multiyear Program Plans, U.S. Department of Energy, Office of Fossil Energy Coal and Power Systems, January 1999. 
22. J. G. Delene, L. C. Fuller, and C. R. Hudson, "ALMR Deployment Economic Analysis," ORNL/TM-12344, Lockheed Martin Energy Systems, Oak Ridge National Laboratory, 1993.

23. H. I. Bowers, L. C. Fuller, and M. L. Myers, Cost Estimating Relationships for Nuclear Power Plant Operation and Maintenance, Lockheed Martin Energy Systems, Inc., Oak Ridge National Laboratory, ORNL/TM-10563, November 1987.

24. J. G. Delene, "Advanced Fission and Fossil Plant Economics-Implications for Fusion," Fusion Technology, 26, 1105-1110 (1994).

25. J. G. Delene et al., "Economic Potential for Future Water Reactors," presented at the American Nuclear Society/European Nuclear Society 1988 International Conference, October 30-November 4, 1988, Washington, D.C.

26. Historic Monthly Energy Review 1973-1992, U.S. Department of Energy, Energy Information Administration, DOE/EIA-0035 (73-92).

27. Cost and Quality of Fuels for Electric Utility Plants 1998, U.S. Department of Energy, Energy Information Administration, Internet-only publication http://www.eia.doe.gov/cneaf/electricity/

28. Historical Natural Gas Annual 1930 Through 1997, U.S. Department of Energy, Energy Information Administration, DOE/EIA-E-0110(97), October 1998.

29. Nuclear Fuel (various issues such as January 15, 1999).

30. Nuclear News Flashes, May 20, 1999.

31. Nuclear Fuel (November 30, 1998).

32. Nucleonics Week, p. 15 (March 18, 1999).

33. H. J. Herzog, "The Economics of $\mathrm{CO}_{2}$ Capture," p. 101-106 in Greenhouse Gas Control Technologies, R. Riemer, B. Eliasson, and A Woxaun, Eds., 1999.

34. "Hydrogen-Today and Tomorrow," p. 12 in IEA Greenhouse Gas R\&D Programme, April 1999.

35. “Ocean Storage of $\mathrm{CO}_{2}$," IEA Greenhouse Gas R\&D Programme, February 1999.

36. Nucleonics Week, p. 15 (March 18, 1999). 


\section{INTERNAL DISTRIBUTION}
1. D. B. Batchelor
2. L. A. Berry
3. M. A. Brown
4. B. A. Carreras
5. T. R. Curlee
6-15. J. G. Delene
16. E. C. Fox
17. R. G. Gilliland
18-19. S. Hadley
20. M. A. Kuliasha
21. R. Lee
22. G. T. Mays
23. G. E. Michaels

\author{
24. S. L. Milora \\ 25. P. K. Mioduszewski \\ 26. D. A. Rasmussen \\ 27-28. R. L. Reid \\ 29-33. J. Sheffield \\ 34. R. B. Shelton \\ 35-39. K. A. Williams \\ 40. D. L. Williams, Jr. \\ 41. Central Research Library \\ 42. Fusion Energy Division Library \\ 43. ORNL Laboratory Records-RC \\ 44-45. ORNL Laboratory Records-OSTI
}

\section{EXTERNAL DISTRIBUTION}

46. W. F. Dove, SC-55, U.S. Department of Energy, 19901 Germantown Rd., Room G-255, Germantown, MD 20874

47. B. G. Logan, Lawrence Livermore National Laboratory, P.O. Box 808, L-644, Livermore, CA 94550

48. W. D. Magwood IV, NE-1, U.S. Department of Energy, Forrestal Bldg., Room 5A-143, 1000 Independence Avenue SW, Washington, DC 20585

49. R. W. Miller, University of California-San Diego, 9599 Gilman Drive, La Jolla, CA 92093 0417

50. R. Moir, Lawrence Livermore National Laboratory, P.O. Box 808, L-637, Livermore, CA 94550

51. F. Najmabadi, 6291 Boelter Hall, University of California, Los Angeles, CA 90024

52. J. M. Stamos, NE-20, U.S. Department of Energy, 19901 Germantown Rd., Room B-406, Germantown, MD 20874 